\title{
Persistent Increase in Hypothalamic Arginine Vasopressin Gene Expression During Protracted Withdrawal from Chronic Escalating-Dose Cocaine in Rodents
}

\author{
Yan Zhou ${ }^{*, '}$, Yoav Litvin², Anna Paola Piras', Donald W Pfaff ${ }^{2}$ and Mary Jeanne Kreek' \\ 'Laboratory of the Biology of Addictive Diseases, The Rockefeller University, New York, NY, USA; ${ }^{2}$ Laboratory of Neurobiology and Behavior, \\ The Rockefeller University, New York, NY, USA
}

\begin{abstract}
Arginine vasopressin (AVP) from the paraventricular nucleus (PVN) of hypothalamus has important roles in regulation of the hypothalamic-pituitary-adrenal (HPA) axis and stress-related behaviors during chronic stress. It is unknown, however, whether AVP in the $P V N$ is involved in the modulation of HPA activity after chronic cocaine exposure. Here, we examined the gene expression alterations of AVP in the hypothalamus, and VIb receptor and pro-opiomelanocortin (POMC) in the anterior pituitary, as well as HPA hormonal changes, in Fischer rats after chronic cocaine and withdrawal, using two different chronic ( 14 -day) 'binge' pattern administration regimens: steady-dose cocaine (SDC, $45 \mathrm{mg} / \mathrm{kg} / \mathrm{day}$ ) and escalating-dose cocaine (EDC, 45 up to $90 \mathrm{mg} / \mathrm{kg} /$ day). There was a significant (7-fold) plasma adrenocorticotropic hormone (ACTH) elevation after chronic EDC (but not SDC), coupled with increased VIb and POMC mRNA levels in the anterior pituitary. From acute (I-day) to protracted (14-day) withdrawal from chronic EDC (but not from SDC), we found persistent elevations of both plasma ACTH and corticosterone levels and AVP mRNA levels in the PVN. Selective VIb antagonist SSRI $494 I 5(5 \mathrm{mg} / \mathrm{kg})$ attenuated acute withdrawal-induced HPA activation after EDC. To study potential roles of endogenous opioids in modulating the AVP gene, we administered naloxone (I mg/kg); we found that opioid receptor antagonism increased AVP mRNA levels in cocaine-naive rats, but not in cocaine-withdrawn rats, suggesting less tonic opioid inhibition of PVN AVP neurons after chronic EDC. To assess the effects of cocaine withdrawal on sub-populations of PVN AVP neurons, we utilized AVP-enhanced green fluorescent protein (EGFP) promoter transgenic mice and found that acute withdrawal following chronic EDC increased the number of AVP-EGFP neurons in the parvocellular PVN (pPVN). These results suggest that during protracted withdrawal, enhanced pPVN AVP gene expression is associated with persistent elevations of basal HPA activity; a hyposensitivity of PVN AVP gene expression to naloxone is indicative of reduced opioidergic tone. Our studies indicate that the AVP and its VIb receptor system may be a potential therapeutic target for treating anxiety and depressive symptoms associated with cocaine addiction.

Neuropsychopharmacology (20II) 36, 2062-2075; doi:I0.1038/npp.20 II.97; published online I5 June 20 I I
\end{abstract}

Keywords: cocaine withdrawal; arginine vasopressin; VIb receptor; SSRI494I5; hypothalamic-pituitary-adrenal axis; AVP-EGFP mice

\section{INTRODUCTION}

There is evidence that cocaine abuse disrupts hypothalamicpituitary-adrenal (HPA) axis function in humans. Cocaine abuse increases plasma adrenocorticotropic hormone (ACTH), $\beta$-endorphin, and cortisol levels (Mendelson et al, 1998). The effects of a single dose of cocaine or of stress on ACTH secretion, however, are significantly lower in cocaine-dependent men than in occasional cocaine users

*Correspondence: Dr Y Zhou, Laboratory of the Biology of Addictive Diseases, The Rockefeller University, 1230 York Avenue, New York, NY 10065, USA, Tel: + I 2123278248 , Fax: + I 2123278574 ,

E-mail: yan.zhou@rockefeller.edu

Received I5 February 201 I; revised I5 April 20II; accepted 9 May 2011 or normal subjects (Mendelson et al, 1998; Brady et al, 2009; Back et al, 2010), showing tolerance as found in the animal model after chronic cocaine administration (Zhou et al, 1996). Higher basal plasma ACTH and cortisol levels have been reported in cocaine addicts 1 day after the cessation of cocaine self-administration (Vescovi et al, 1992). In cocaine addicts with depressive symptoms, basal plasma cortisol levels are increased during early cocaine abstinence (Elman et al, 1999; Buydens-Branchey et al, 2002), an effect that may persist weeks and even months during abstinence (Contoreggi et al, 2003; Wilkins et al, 2005). However, other clinical studies have reported that after a brief period of abstinence, basal and corticotropin-releasing factor (CRF)stimulated ACTH and cortisol levels in cocaine-dependent patients do not differ from those of healthy subjects (Mendelson et al, 1998; Jacobsen et al, 2001; Aouizerate 
et al, 2006). Psychological stressors or CRF elevate cocaine craving and HPA activity, and stress-induced ACTH and cortisol responses predict subsequent cocaine relapse (Sinha et al, 2006; Brady et al, 2009).

In rodents, stress can increase the secretion of CRF and arginine vasopressin (AVP) into the pituitary portal circulation from terminals of the parvocellular division of the paraventricular nucleus (pPVN) of the hypothalamus, and AVP potentiates CRF-induced ACTH secretion from the anterior pituitary into circulation (Gillies et al, 1982; Rivier and Vale, 1983; Knepel et al, 1985; Antoni, 1993; Herman, 1995; McEwen, 2007). Acute cocaine stimulates the HPA axis in animal models of drug abuse (Moldow and Fischman, 1987; Borowsky and Kuhn, 1991). Although chronic 'binge' cocaine administration in a steady-dose regimen significantly elevates plasma corticosterone (CORT) levels, this effect was significantly blunted in comparison with the effects of acute cocaine on the HPA axis, indicating a tolerance to the same dose of cocaine (Zhou et al, 1996). The development of tolerance to the stimulatory effect on the HPA axis by cocaine is associated with a significant reduction in CRF mRNA levels in the hypothalamus, and this relative CRF deficiency probably results from a dopamine $\mathrm{D}_{1}$-like (but not $\mathrm{D}_{2}$-like) receptormediated mechanism (Zhou et al, 1996; Kreek et al, 2009).

Although an earlier study has shown that only CRF, but not AVP, contributes to the acute stimulatory effects of cocaine on HPA activity (Rivier and Lee, 1994), we predicted an effect of chronic, but not acute, cocaine on the AVP stress responsive system, based on evidence showing a preferential activation of AVP gene expression in the pPVN after chronic stress (Aguilera, 1994; Kovacs and Sawchenko, 1996). However, it is unknown whether AVP synthesized in the pPVN or its target $\mathrm{V} 1 \mathrm{~b}$ receptor in the anterior pituitary is involved in the modulation of HPA activity after chronic cocaine or its withdrawal.

The present studies were conducted in Fischer rats to determine the effect of chronic 'binge' cocaine and withdrawal on alterations: (1) AVP gene expression in the PVN, (2) V1b receptor and pro-opiomelanocortin (POMC) gene expression in the anterior pituitary, and (3) plasma ACTH and CORT levels. Both chronic 14-day steady-dose cocaine (SDC, $45 \mathrm{mg} / \mathrm{kg} /$ day) regimen (partial HPA axis tolerance developed) and escalating-dose cocaine (EDC) regimen (the initial cocaine dose $(45 \mathrm{mg} / \mathrm{kg})$ doubled over 14-day chronic exposure) were used. In fact, different alterations of orexin and preprodynorphin mRNA levels in the lateral hypothalamus were found following acute cocaine withdrawal from chronic escalating-dose and steady-dose 'binge' pattern regimens (Zhou et al, 2008a). The effect of a pharmacological blockade of the $\mathrm{V} 1 \mathrm{~b}$ receptor with the selective antagonist SSR149415 was evaluated by assessing its effects on the HPA axis response to acute cocaine withdrawal. Second, we addressed whether opioid receptors are involved in the modulation of hypothalamic AVP mRNA in cocaine withdrawal. For this purpose, we assessed the effects of the opioid receptor antagonist naloxone on PVN AVP mRNA levels during chronic cocaine withdrawal in rats. To study sub-populations of hypothalamic AVP neurons, including the parvocellular and magnocellular division of the PVN, the supraoptic nucleus (SON), and the medial preoptic area (MPOA), we examined the effects of acute cocaine with- drawal using BAC transgenic mice, in which AVP-expressing neurons were labeled with enhanced green fluorescent protein (EGFP).

\section{MATERIALS AND METHODS}

Experiment 1: Withdrawal from Chronic (14-day)
Escalating-Dose 'Binge' Pattern Cocaine Administration
and Interactions with Naloxone and SSR149415 in Rats

Animals. Male Fischer 344 rats (190-220 g; Charles River Labs, Kingston, NY) were housed individually in a stressminimized facility with free access to food and water. In order to minimize stress, noise and animal handling unrelated to the experimental protocol were kept to a bare minimum. Animals were adapted to a standard 12-h light/ dark cycle (lights on from 900 to $2100 \mathrm{~h}$ ) for 7 days before the beginning of the experiment. The protocol was approved by the Rockefeller University Animal Care and Use Committee.

Fischer rats were selected because this inbred strain with high anxiety phenotype self-administers cocaine at a high level after cocaine self-administration behavior is established (Kosten and Ambrosio, 2002; Picetti et al, 2010).

Procedure of escalating-dose 'binge' pattern cocaine administration and withdrawal with naloxone or SSR149415 pretreatment. The 'binge' pattern regimen of drug exposure (saline or cocaine) consisted of intraperitoneal (ip) injections in the home cage three times daily with two 1-h intervals, beginning $30 \mathrm{~min}$ after the light cycle (9:30, 10:30, and 11:30) (Zhou et al, 1996). This dosing schedule was chosen to mimic the pattern often observed in human cocaine abusers with respect to repeated administrations over several hours, with relation to the circadian rhythm of rest and activity. For animals treated with cocaine, the doses were increased after every 3 days. Therefore, the cocaine-treated rats received initial dosing at $45(3 \times 15) \mathrm{mg} / \mathrm{kg} /$ day on days $1-3,60(3 \times 20) \mathrm{mg} / \mathrm{kg} /$ day on days $4-6,75(3 \times 25) \mathrm{mg} / \mathrm{kg} /$ day on days $7-9$, and then $90(3 \times 30) \mathrm{mg} / \mathrm{kg} /$ day on days $10-14$. As previously reported, this dosing schedule models the dose range selfadministered by rats given long access $(6-10 \mathrm{~h})$ to cocaine (Koob and Kreek, 2007).

The experiment paradigm consisted of three phases: chronic 14-day escalating-dose 'binge' pattern cocaine administration, acute 1-day withdrawal, and chronic 14-day withdrawal (Figure 1a).

In Experiment 1.1, chronic (14-day) escalating-dose 'binge' cocaine, rats received escalating-dose 'binge' cocaine (from 45 up to $90 \mathrm{mg} / \mathrm{kg} /$ day) $(n=8)$ or saline $(n=8)$ injections for 14 days and were then killed at $1200 \mathrm{~h}$ on day $14,30 \mathrm{~min}$ after the last 'binge' cocaine or saline injection. During exposure to $90 \mathrm{mg} / \mathrm{kg} /$ day dose of cocaine, two rats died with seizures, resulting in an $n=6$ for the cocainetreated group.

In Experiment 1.2, acute (1-day) cocaine withdrawal with naloxone, rats received 'binge' cocaine (from 45 up to $90 \mathrm{mg} / \mathrm{kg} /$ day) or saline injections for 14 days and were then killed at $1200 \mathrm{~h}$ on day 15,1 day after the last 'binge' cocaine or saline injection. On day 14 (1 day before kill for sampling), an ip injection of naloxone $(1 \mathrm{mg} / \mathrm{kg})$ or saline 
a Chronic (14-day) escalating-dose (45 up to $90 \mathrm{mg} / \mathrm{kg} / \mathrm{day}$ ) "binge" cocaine, acute (1-day) withdrawal (WD) and chronic (14-day) WD with opioid receptor antagonist naloxone or V1b receptor antagonist SSR149415

\begin{tabular}{|c|c|c|c|c|c|c|c|}
\hline \multirow[b]{2}{*}{ Cocaine } & Days 1-3 & Days 4-6 & Days 7-9 & Days $10-14$ & Day 15 & & Day 28 \\
\hline & $\begin{array}{c}15 \times 3 \\
\mathrm{mg} / \mathrm{kg} / \text { day }\end{array}$ & $\begin{array}{c}20 \times 3 \\
\mathrm{mg} / \mathrm{kg} / \mathrm{day}\end{array}$ & $\begin{array}{c}25 \times 3 \\
\mathrm{mg} / \mathrm{kg} / \text { day }\end{array}$ & $\begin{array}{c}30 \times 3 \\
\mathrm{mg} / \mathrm{kg} / \mathrm{day}\end{array}$ & 1-day WD & & 14-day WD \\
\hline \multirow{2}{*}{$\begin{array}{c}\text { Naloxone } \\
\text { SSR149415 }\end{array}$} & & & & Day 14 & & $\begin{array}{l}\text { Day } 26 \\
\end{array}$ & \\
\hline & & & & Day 14 & Day 15 & & \\
\hline
\end{tabular}

b Chronic (14-day) steady-dose (45 mg/kg/day) "binge" cocaine, acute (1-day) withdrawal (WD) and chronic (10-day) WD

\begin{tabular}{|c|c|c|c|c|c|c|}
\hline & Days 1-3 & Days 4-6 & Days 7-9 & Days 10-14 & Day 15 & Day 24 \\
\hline DC & $\begin{array}{c}15 \times 3 \\
\mathrm{mg} / \mathrm{kg} / \mathrm{day}\end{array}$ & $\begin{array}{c}15 \times 3 \\
\mathrm{mg} / \mathrm{kg} / \mathrm{day}\end{array}$ & $\begin{array}{c}15 \times 3 \\
\mathrm{mg} / \mathrm{kg} / \text { day }\end{array}$ & $\begin{array}{c}15 \times 3 \\
\mathrm{mg} / \mathrm{kg} / \mathrm{day}\end{array}$ & 1-day WD & 10-day WD \\
\hline
\end{tabular}

Figure I Timelines for cocaine administration regimens with antagonist applications.

was administered $30 \mathrm{~min}$ after the last 'binge' cocaine or saline injection. In this experiment, rats were assigned to one of four treatment groups: (1) Acute cocaine withdrawal: cocaine injections for 14 days with one saline injection $30 \mathrm{~min}$ after the last 'binge' cocaine, followed by 1-day withdrawal, $n=7$ (during exposure to $90 \mathrm{mg} / \mathrm{kg} /$ day dose of cocaine, one died with seizures resulting in an $n=6$ ); (2) Saline control: saline injections for 14 days with one saline injection $30 \mathrm{~min}$ after the last 'binge' saline, followed by 1-day withdrawal, $n=6$; (3) Naloxone + Acute cocaine withdrawal: cocaine injections for 14 days with one naloxone injection $(1 \mathrm{mg} / \mathrm{kg}) 30 \mathrm{~min}$ after the last 'binge' cocaine, followed by 1 -day withdrawal, $n=7$; and (4) Naloxone: saline injections for 14 days with one naloxone injection $(1 \mathrm{mg} / \mathrm{kg}) 30 \mathrm{~min}$ after the last 'binge' saline, followed by 1 -day withdrawal, $n=6$. The naloxone dose chosen was based on our previous study, in which a single $1 \mathrm{mg} / \mathrm{kg}$ dose was observed to moderately increase ACTH levels in cocaine-naive rats after $3 \mathrm{~h}$ of injection (Zhou et al, 2005).

In Experiment 1.3, chronic (14-day) cocaine withdrawal with naloxone, rats received 'binge' cocaine (from 45 up to $90 \mathrm{mg} / \mathrm{kg} / \mathrm{day}$ ) or saline injections for 14 days and were then killed at $1200 \mathrm{~h}$ on day 28,14 days after the last 'binge' cocaine or saline injection. On day 26 (2 days before kill for sampling), an ip injection of naloxone $(1 \mathrm{mg} / \mathrm{kg}$ ) or saline was administered. In this experiment, rats were assigned to one of four treatment groups: (1) Chronic cocaine withdrawal: cocaine injections for 14 days followed by 14-day withdrawal, with one saline injection on day $26, n=7$ (during exposure to $90 \mathrm{mg} / \mathrm{kg} /$ day dose of cocaine, one rat died with seizures, resulting in an $n=6$ ); (2) Saline control: saline injections for 14 days followed by 14-day withdrawal, with one saline injection on day $26, n=6$; (3) Naloxone + Chronic cocaine withdrawal: cocaine injections for 14 days followed by 14-day withdrawal, with one naloxone injection $(1 \mathrm{mg} / \mathrm{kg})$ on day $26, n=8$; and (4) Naloxone: saline injections for 14 days followed by 14-day withdrawal, with one naloxone injection $(1 \mathrm{mg} / \mathrm{kg})$ on day $26, n=6$.

In Experiment 1.4, acute (1-day) cocaine withdrawal with SSR149415, the pattern and dose of drug injections (saline or cocaine), treatment groups, and kill time point were identical to those in Experiment 1.2. SSR149415 (a gift from Dr G Griebel, Sanofi Aventis, Montpellier, France) was suspended in 5\% DMSO and 5\% Cremophor in saline. On day 14 (1 day before kill for sampling), an ip injection of SSR149415 $(5 \mathrm{mg} / \mathrm{kg})$ or vehicle was administered $30 \mathrm{~min}$ after the last 'binge' cocaine or saline injection. On day 15 ( 30 min before kill for sampling), the second ip injection of SSR149415 (5 mg/kg/injection) or vehicle was administered. In this experiment, rats were assigned to one of four treatment groups: (1) Acute cocaine withdrawal: $n=8$; (2) Saline control: $n=6$; (3) SSR149415 + Acute cocaine withdrawal: $n=6$; and (4) SSR149415: $n=6$. The SSR149415 dose chosen was based on previous studies, in which $1-30 \mathrm{mg} / \mathrm{kg}$ doses were observed to efficiently block HPA activation induced by a variety of stressors (Serradeil-Le Gal et al, 2002; Zhou et al, 2008b; Roper et al, 2011).

All rats were rapidly decapitated after brief exposure to $\mathrm{CO}_{2}$ (within $15 \mathrm{~s}$ ), and the PVN (PVN rich dissection without SON), anterior pituitary, neuro-intermediate lobe/ posterior lobe (NIL/PL), and plasma were collected for subsequent mRNA and hormonal analyses. The PVN in the hypothalamus was selected because recent studies have demonstrated that activation of the AVP/V1b receptor system in the hypothalamus is involved in 'anxiety'-related and 'depression'-like behaviors in rodents (Wigger et al, 2004).

Preparation of RNA extracts. In each experiment, rats were killed by decapitation after a brief exposure to $\mathrm{CO}_{2}$. Each animal brain was removed from the skull and placed in a chilled rat brain matrix (ASI Instruments, Houston, TX). A coronal slice containing the hypothalamus was removed from the matrix and placed on a chilled petri dish. Dissection was carried out using razor blades and forceps under a dissecting microscope. The PVN brain section was identified at the levels of Bregma -1.80 to $-2.56 \mathrm{~mm}$ according to The Rat Brain in Stereotaxic Coordinates (Paxinos and Watson, Academic Press, New York, 1986). The PVN was dissected as a reversed isosceles triangle, $1.0 \mathrm{~mm}$ bilateral to the third ventricle and between the fornix structures, was under a microscope using the fornix and third ventricle as landmarks. The anterior pituitary and NIL/PL were also dissected, and all three regions were homogenized in guanidinium thiocyanate buffer and extracted with acidic phenol and chloroform. After the final ethanol precipitation step, each extract was resuspended in DEPC-treated $\mathrm{H}_{2} \mathrm{O}$ and stored at $-80^{\circ} \mathrm{C}$.

$A V P, V 1 b$ receptor, and POMC mRNA measurements using solution hybridization ribonuclease protectiontrichloroacetic acid precipitation assay. The solution 
hybridization ribonuclease (RNase) protection-trichloroacetic acid (TCA) precipitation protocol has been described in detail in earlier reports (Zhou et al, 1996). A 502-bp fragment from the rat AVP cDNA or a 1201-bp fragment from the rat $\mathrm{V} 1 \mathrm{~b}$ receptor cDNA was cloned into the polylinker region of pCR II (Invitrogen, Carlsbad, CA). A 538-bp fragment from the rat POMC cDNA was cloned into the polylinker region of either pSP64 or pSP65 plasmids (Promega, Madison, WI) in both the sense and antisense orientations. The plasmid pS/E (a pSP65 derivative) was used to synthesize riboprobe for the $18 \mathrm{~S}$ rRNA to determine total RNA. ${ }^{33}$ P-labeled cRNA antisense probes and unlabeled cRNA sense standards were synthesized using SP6, T3, or T7 transcription system. A denaturing agarose gel $(1.0 \mathrm{M}$ formaldehyde) showed that a single full-length transcript had been synthesized from each plasmid.

RNA extracts were dried in $1.5 \mathrm{ml}$ Eppendorf tubes and resuspended in $30 \mu \mathrm{l}$ of $2 \times$ TESS $(10 \mathrm{mM} \mathrm{N}$-Tris[hydroxymethyl]methyl-2-aminoethane sulfonic acid, $\mathrm{pH}$ 7.4; $10 \mathrm{mM}$ EDTA; $0.3 \mathrm{M} \mathrm{NaCl} ; 0.5 \%$ sodium dodecyl sulfate [SDS]) that contained $150-300 \mathrm{~K} \mathrm{cpm}$ of a probe. Samples were covered with mineral oil and hybridized overnight at $75^{\circ} \mathrm{C}$. For RNase treatment, $250 \mu \mathrm{l}$ of a buffer containing $0.3 \mathrm{M} \mathrm{NaCl}$, $5 \mathrm{mM}$ EDTA, $10 \mathrm{mM}$ Tris- $\mathrm{HCl}$ (pH 7.5), $40 \mu \mathrm{g} / \mathrm{ml}$ RNase A (Worthington Biochemical, Freehold, NJ) and $2 \mu \mathrm{g} / \mathrm{ml}$ RNase T1 (Calbiochem, San Diego, CA) were added and each sample was incubated at $30^{\circ} \mathrm{C}$ for $1 \mathrm{~h}$. TCA precipitation was effected by the addition of $1 \mathrm{ml}$ of a solution that contained 5\% TCA and $0.75 \%$ sodium pyrophosphate. Precipitates were collected onto a filter in sets of 24 using a cell harvester (Brandel, Gaithersburg, MD) and were measured in a scintillation counter with liquid scintillant (Beckman, Palo Alto, CA).

The procedure to measure mRNA levels involved a comparison of values obtained from experimental samples (brain extracts) to those obtained for a set of calibration standards. The calibration standards had known amounts of an in vitro sense transcript whose concentration was determined by optical absorbance at $260 \mathrm{~nm}$. The set of calibration standards included those with no added sense transcript and those that contained between 1.25 and $80 \mathrm{pg}$ of the sense transcript. A new standard curve was generated each time experimental samples were analyzed and all extracts of a particular tissue were assayed for each mRNA levels as a group in a single assay. Total cellular RNA concentrations were measured by hybridization of diluted extracts to a ${ }^{33} \mathrm{P}$-labeled probe complementary to $18 \mathrm{~S}$ rRNA at $75^{\circ} \mathrm{C}$. The calibration standards for this curve contained $10 \mu \mathrm{g}$ of E. coli tRNA plus either 0.0 , or from 2.5 to $40 \mathrm{ng}$ of total RNA from rat brain whose concentration was determined by optical absorbance at $260 \mathrm{~nm}$.

CRF mRNA measurement using real-time RT-PCR. The protocol is described in detail below in the single-cell realtime reverse-transcribed (RT)-PCR section. Briefly, mRNA from the PVN was reverse-transcribed (RT reaction) into cDNA using $5 \mu \mathrm{l}$ of RNase/DNase-free water containing the mRNA. RT was followed by real-time PCR, and mRNA samples were tested for CRF mRNA and 18S rRNA. Primer pairs were designed for CRF (Assay ID Rn01462137m1)
(Primer Express, Applied Biosystems, Carlsbad, CA). Conditions for the cycles and controls were identical to the AVP assay.

Radioimmunoassays. At the time of decapitation, blood from each animal was collected in tubes, placed on ice, and spun in a refrigerated centrifuge. Plasma was separated and stored at $-40{ }^{\circ} \mathrm{C}$ for hormonal measurements by radioimmunoassay. Plasma ACTH immunoreactivity levels were assayed from unextracted plasma by using a kit from Nichols Institute (San Juan Capistrano, CA). Plasma CORT levels were assayed using a rat/mouse CORT ${ }^{125} \mathrm{I}$ kit from MP Biomedicals (Costa Mesa, CA). All values were determined in duplicate in a single assay.

\section{Experiment 2: Withdrawal from Chronic (14-day) Steady-Dose 'Binge' Pattern Cocaine Administration in Rats}

Animals. A new cohort of rats identical to those used in Experiment 1.

Procedure for steady-dose 'binge' pattern cocaine administration and withdrawal. The 'binge' pattern of drug exposure (saline or cocaine), injection route, and time points were identical to those in Experiment 1. For animals treated with cocaine, the dose was $3 \times 15 \mathrm{mg} / \mathrm{kg}$ every day, and there was no animal loss using this dose. The experiment paradigm is shown in Figure $1 b$.

In separate experiments, animals were subjected to acute (1-day) or chronic (14-day) steady-dose 'binge' cocaine $(3 \times 15 \mathrm{mg} / \mathrm{kg}, \quad n=6)$, while control animals received equivalent treatment with saline $(n=6)$. Animals were killed at $1200 \mathrm{~h}$ either $30 \mathrm{~min}$ (Experiment 2.1 after acute cocaine and Experiment 2.2 after chronic cocaine), 1 day (Experiment 2.3 after chronic cocaine) or 10 days (Experiment 2.4 after chronic cocaine) following their last cocaine injection.

The PVN, anterior pituitary, NIL/PL, and plasma were collected for subsequent mRNA and hormonal analyses, as described in the above Experiment 1 section.

\section{Experiment 3: Withdrawal from Chronic (14-day) Escalating-Dose 'Binge' Pattern Cocaine Administration in AVP-EGFP Promoter Transgenic Mice}

Animals. AVP-EGFP mice (a gift from Dr N Heintz at The Rockefeller University in New York) were made by homologous recombination of an AVP gene-containing BAC comprising an EGFP insert, in which the AVP promoter drives EGFP expression (Gong et al, 2003), and maintained on a Swiss-Webster background. Littermate male mice (AVP-EGFP positive $(+)$ heterozygous and negative (-)) weighing 29-39g (4-6 months of age) used in the present study were housed individually in a stressminimized facility as described above for rats, and screened by PCR analysis of genomic DNA extracted from mouse tail biopsies.

Procedure of escalating-dose 'binge' pattern cocaine administration and withdrawal. The 'binge' pattern of 
drug exposure (saline or cocaine), injection route, and time points were identical to those of escalating-dose 'binge' cocaine administration in Experiment 1.

In Experiment 3, acute ( 1 day) cocaine withdrawal, both $\operatorname{AVP}-\operatorname{EGFP}(+)$ and AVP-EGFP(-) mice received escalating-dose 'binge' cocaine (from 45 up to $90 \mathrm{mg} / \mathrm{kg} /$ day) or saline injections for 14 days and were then killed at $1200 \mathrm{~h}$ on day 15, 1 day after the last 'binge' cocaine or saline injection. In this experiment, mice were assigned to one of four treatment groups: (1) Acute cocaine withdrawal in $\operatorname{AVP-EGFP}(+)$ mice: cocaine injections for 14 days followed by 1-day withdrawal, $n=8$ (during exposure to $90 \mathrm{mg} / \mathrm{kg} /$ day dose of cocaine, one mouse died with seizures resulting in an $n=7$ ); (2) Saline control in AVP-EGFP $(+)$ mice: saline injections for 14 days followed by 1-day withdrawal, $n=7$; (3) Acute cocaine withdrawal in AVPEGFP(-) mice: cocaine injections for 14 days followed by 1-day withdrawal, $n=7$ (during exposure to highest dose of cocaine, one animal died with seizures and then $n=6$ ); and (4) Saline control in AVP-EGFP(-) mice: saline injections for 14 days followed by 1-day withdrawal, $n=6$.

AVP-EGFP $(+)$ mice were killed for fluorescent microscopic observation (see below). In the AVP-EGFP(-) mice, the PVN identified according to The Mouse Brain in Stereotaxic Coordinates (Paxinos and Franklin, Academic Press, San Diego, CA, 1997) was collected for AVP mRNA analysis as described in the above Experiment 1 section. Plasma was collected from both AVP-EGFP $(+)$ and AVPEGFP(-) mice for CORT analyses, as described in the above Experiment 1 section.

Fluorescent microscopic observation for AVP-EGFPexpressing cells. AVP-EGFP $(+)$ mice were deeply anesthetized using sodium pentobarbital $(75 \mathrm{mg} / \mathrm{kg}$, ip), and then perfused via the left ventricle with $100 \mathrm{mM}$ phosphatebuffered saline (PBS, pH 7.4) containing heparin, followed by $4 \%$ paraformaldehyde in PBS. After postfixation, the brains were equilibrated in PBS containing 30\% sucrose for $48 \mathrm{~h}$ at $4{ }^{\circ} \mathrm{C}$. As previously described (Nomura et al, 2002), brains were coronally sectioned at $20 \mu \mathrm{m}$ on a freezing microtome, and stored in cryoprotectant $(2.5 \%$ glycerol and $25 \%$ sucrose in PBS) at $-20^{\circ} \mathrm{C}$ until they were used.

All sections obtained from cocaine- and saline-treated $\operatorname{AVP-EGFP}(+)$ mice were processed at the same time. Floating sections were washed thoroughly in PBS to remove cryoprotectant, and then mounted onto gelatin-coated glass slides, air-dried, and coverslipped with aqueous mounting media Fluoro-Gel (EMS, Hatfield, PA). For each animal after either saline or cocaine withdrawal treatment, three sections containing the anatomically matched levels of middle part of the PVN (Bregma -0.70 to $-0.82 \mathrm{~mm}$ ), two sections of the SON (Bregma -0.58 to $-0.70 \mathrm{~mm}$ ), or MPOA (Bregma 0.02 to $-0.1 \mathrm{~mm}$ ) were defined and selected according to The Mouse Brain in Stereotaxic Coordinates (Paxinos and Franklin, Academic Press, San Diego, CA, 1997). Sections from these brain areas were examined using a fluorescent microscope (Zeiss) with a GFP filter (Nikon), and the images were captured with Zeiss LSM 510 (version 3.2) software to investigate AVP-EGFP expression in the PVN, SON, MPOA, the bed nucleus of the stria terminalis and medial amygdala. AVP-EGFP-expressing cells were counted by a single observer who was unaware of the treatment of the samples. The average numbers of AVP-EGFP cells/ section (combined two sides) in each brain region were calculated for each animal.

Immunohistochemistry (IHC) for AVP. As described recently (Westberg et al, 2009), floating sections from two male AVP-EGFP $(+)$ mice were washed several times in PBS and then blocked with PBS containing 3\% normal donkey serum and $0.5 \%$ Triton X-100. Floating sections were incubated in a rabbit polyclonal anti-AVP primary antibody $(1: 1000$, MP Biomedicals, Solon, $\mathrm{OH})$ for $48 \mathrm{~h}$ at $4{ }^{\circ} \mathrm{C}$. The sections were further incubated with a $1: 200$ dilution of the cy3-conjugated donkey anti-rabbit secondary antibody (ImmunoResearch Laboratories, West Grove, PA) in PBS containing $0.5 \%$ Triton X-100 and $1.5 \%$ normal donkey serum for $120 \mathrm{~min}$ at room temperature. Sections were then mounted on gelatin-coated slides, air-dried, and coverslipped with Fluoro-Gel. As described above, sections in the PVN and MPOA were examined using a fluorescence microscope (Zeiss) with a GFP filter (Nikon), and the images were captured with Zeiss LSM 510 (version 3.2) software to investigate AVP-like immunoreactivity and AVP-EGFP expression.

Single-cell real-time RT-PCR. AVP-EGFP $(+)$ mice were anesthetized with urethrane (1-1.5 g/kg; Sigma, Chemicals, Perth, WA) and their brains were rapidly removed and immersed in ice-cold $\left(4{ }^{\circ} \mathrm{C}\right)$ oxygenated sucrose-based solution. The area of the brain containing the PVN was blocked and glued to the stage of a vibrating microtome (Leica VT1000S). Coronal slices including the PVN ( 200$250 \mu \mathrm{m}$ thick) were obtained and transferred to a holding chamber containing oxygenated bath solution. The recording chamber was mounted on a Nikon Eclipse E600FN microscope with both fluorescent and infrared differential interference contrast optics. AVP-EGFP-positive cells were, thus, easily identified under the microscope. Borosilicate glass thin-walled pipettes (Warner Instruments, Hamden, CT) were pulled by using a Narishige micropipette puller (PP-830) and filled with $8 \mu \mathrm{l}$ of nuclease-free water (Ambion, Austin, TX). A single $\operatorname{EGFP}(+)$ or $\operatorname{EGFP}(-)$ cell from PVN was aspirated into a pipette under visual control by applying gentle negative pressure (verified under fluorescence microscopy). The pipette was then broken into a 0.2-ml PCR tube (Molecular BioProducts, San Diego, CA), releasing its content. PCR tubes were immediately frozen at $-80^{\circ} \mathrm{C}$.

The collected mRNA was reverse-transcribed (RT reaction) into cDNA $\left(1 \mathrm{~h}\right.$ at $37^{\circ} \mathrm{C}$, Programmable Thermal Controller, MJ Research, Cambridge, MA) following the manufacturer's protocol (Applied Biosystems): $11.75 \mu \mathrm{l}$ of RNase-free water, $2.2 \mu \mathrm{l}$ of $10 \times$ TaqMan RT Buffer, $2.0 \mu \mathrm{l}$ of dNTPs mixture, $0.5 \mu$ of random hexamers, $0.55 \mu$ l MultiScribe reverse transcriptase, and $8 \mu \mathrm{l}$ of RNase/DNase-free water containing the mRNA of the cell. RT was followed by real-time PCR using the TaqMan detection system and the Prism 7700 (both Applied Biosystems). Both EGFP and nonEGFP neurons from the PVN were tested for AVP mRNA and 18S rRNA ('housekeeping' gene). Primer pairs were designed for AVP (Assay ID Mm0043761) and 18S 
(Assay ID 4352930E) (Primer Express, Applied Biosystems). Conditions for the cycles were as follows: PCR UNG enzyme cleanup step, $2 \mathrm{~min}$ at $50{ }^{\circ} \mathrm{C}$; DNA polymerase activation for $10 \mathrm{~min}$ at $95^{\circ} \mathrm{C} ; 40$ cycles of denaturation $15 \mathrm{~s}$ at $95^{\circ} \mathrm{C}$; and annealing + extension for $1 \mathrm{~min}$ at $60^{\circ} \mathrm{C}$. Total volume of PCR in each well was $20 \mu \mathrm{l}: 10 \mu \mathrm{l}$ of TaqMan PCR Master Mix, $1 \mu \mathrm{l}$ of primer, $4 \mu \mathrm{l}$ water, and $5 \mu \mathrm{l}$ of cDNA. Results were analyzed using Prism 7000 sds software (Applied Biosystems).

Control groups included (1) to eliminate the possibility of genomic DNA contamination, EGFP and non-EGFP neurons (two each) were processed without the MultiScribe reverse transcriptase (replaced by $0.55 \mu \mathrm{l}$ RNase-free water) and (2) to eliminate the possibility of a general contamination of the TaqMan PCR Master Mix, primers or RNase/DNase-free water, samples were tested without neurons altogether (replaced by $8 \mu \mathrm{l}$ RNase-free water).

\section{Data Analysis}

In Experiments 1.2, 1.3, and 1.4, group differences were analyzed using two-way ANOVA for acute or chronic withdrawal (cocaine and saline) and for antagonist (naloxone or SSR149415, saline) followed by NewmanKeuls post hoc tests. In other experiments, differences between two groups were analyzed using a two-tailed Student's $t$-test for each measure. The accepted level of significance for all tests was $p<0.05$. All statistical analyses were performed using Statistica (version 5.5, StatSoft, Tulsa, OK).
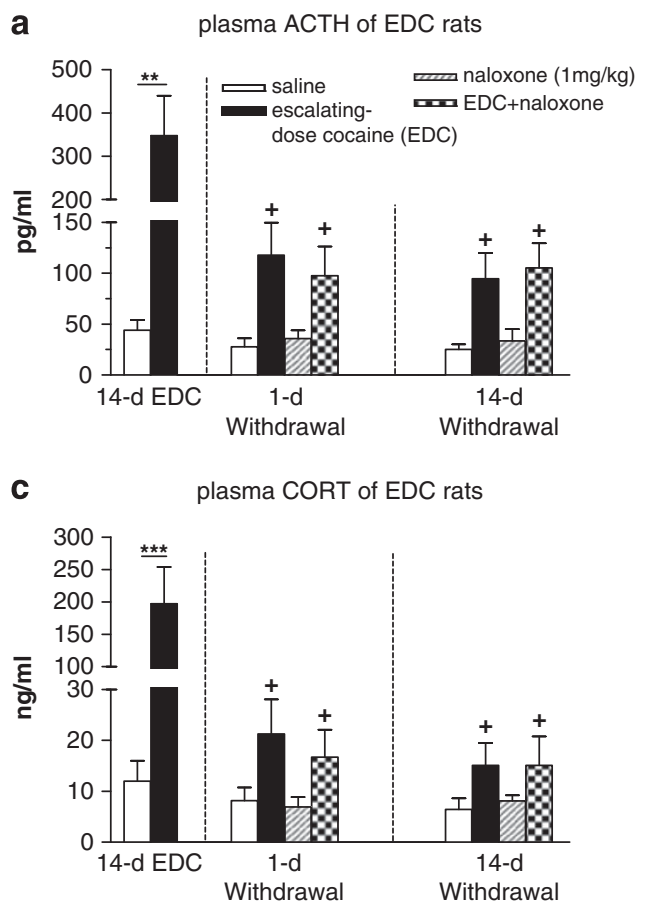

\section{RESULTS}

Experiments 1 and 2: Withdrawal from Different 'Binge' Patterns of Cocaine Administration and Interactions with Naloxone and SSR149415 in Rats

\section{Effects on plasma ACTH and CORT levels.}

Fourteen-day steady-or escalating-dose 'binge' pattern cocaine administration: As shown in Figure 2a, there was a significant increase in plasma ACTH levels after 14 days of escalating-dose 'binge' cocaine administration ( $t=10.7$, $\mathrm{df}=8, p<0.01)$. There was also a significant increase in plasma CORT levels after 14 days of escalating-dose regimen $(t=12.8, \mathrm{df}=9, p<0.005$; Figure $2 \mathrm{c})$.

As shown in Figure 2b, however, plasma ACTH levels after 14 days of chronic steady-dose 'binge' cocaine administration did not significantly differ from the saline control. Plasma CORT levels after 14 days of steady-dose regimen were still significantly elevated $(t=6.8, \mathrm{df}=9$, $p<0.05$; Figure 2d).

One-day withdrawal from 14-day steady-or escalatingdose 'binge' cocaine with or without naloxone: For 1-day withdrawal from chronic EDC, two-way ANOVA showed a significant effect of 1-day withdrawal on plasma ACTH levels $\left(\mathrm{F}_{(1,21)}=5.35, p<0.05\right.$; Figure 2a). However, there was no significant effect of either naloxone or 1-day withdrawal $\times$ naloxone interactions. Also, two-way ANOVA showed a significant effect of 1-day withdrawal on plasma CORT levels $\left(\mathrm{F}_{(1,19)}=6.72, p<0.05\right.$; Figure $\left.2 \mathrm{c}\right)$. Similarly to ACTH levels, there was no significant effect of either naloxone or 1-day withdrawal $\times$ naloxone interactions.
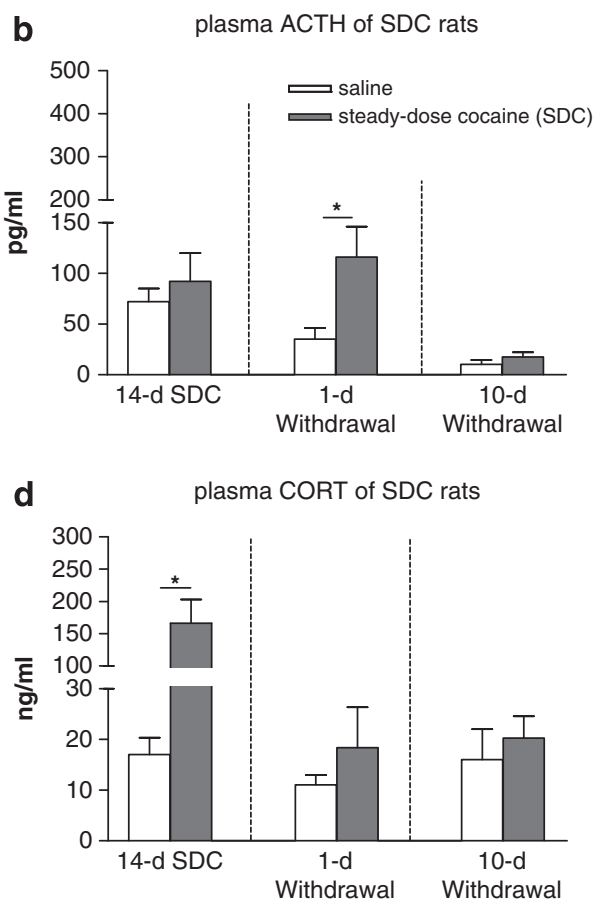

Figure 2 Effects of chronic (I4-day) escalating-dose (45 up to $90 \mathrm{mg} / \mathrm{kg} / \mathrm{day}$ ) 'binge' cocaine (EDC) or chronic (I4-day) steady-dose (45 mg/kg/day) 'binge' cocaine (SDC), acute (I-day) withdrawal and chronic (I0- or |4-day) withdrawal with opioid receptor antagonist naloxone (I mg/kg) on plasma ACTH levels $(a, b)$ and corticosterone (CORT) levels $(c, d)$. Data shown in graphs are treatment group mean + SEM. Significant differences are indicated: $* p<0.05$, $* * p<0.01$ or $* * * *<0.005$ vs saline control; $+p<0.05$, two-way ANOVA with a significant main effect for I-day or I4-day cocaine withdrawal $(n=6-7)$. 
After 1-day withdrawal from chronic steady-dose 'binge' cocaine, there was a significant increase in plasma ACTH levels $(t=6.61, \mathrm{df}=9, p<0.05$; Figure $2 \mathrm{~b})$. However, plasma CORT levels after 1-day withdrawal were not significantly different from the control (Figure 2d).

Fourteen-day withdrawal from 14-day steady- or escalating-dose 'binge' cocaine with or without naloxone: For 14-day withdrawal from chronic EDC (Figure 2a), twoway ANOVA showed a significant effect of 14-day withdrawal on plasma ACTH levels $\left(\mathrm{F}_{(1,21)}=4.91, p<0.05\right)$. However, there was no significant effect of either naloxone or 14-day withdrawal $\times$ naloxone interactions. Also, twoway ANOVA showed a significant effect of 14-day withdrawal on plasma CORT levels $\left(\mathrm{F}_{(1,19)}=5.81, p<0.05\right.$; Figure 2c). Similarly to ACTH levels, there was no significant effect of either naloxone or 14-day withdrawal $\times$ naloxone interactions.

There was no significant effect on either plasma ACTH levels or CORT levels after 10 days of withdrawal from chronic steady-dose 'binge' cocaine (Figure $2 \mathrm{~b}$ and $\mathrm{d}$ ).

One-day withdrawal from 14-day escalating-dose 'binge' cocaine with SSR149415: Two-way ANOVA showed a significant effect of SSR149415 on plasma ACTH levels $\left(\mathrm{F}_{(1,22)}=6.16, p<0.05\right.$; Figure 3a). Although Newman-Keuls post hoc tests just failed to show a significant difference between saline and 1-day withdrawal groups $(p=0.057)$, planned comparisons revealed that (1) plasma ACTH levels were significantly increased in 1-day withdrawal $\left(\mathrm{df}_{(1,22)}=4.32, \quad p<0.05\right)$ and (2) pretreatment with

a plasma ACTH of 1-day withdrawn rats
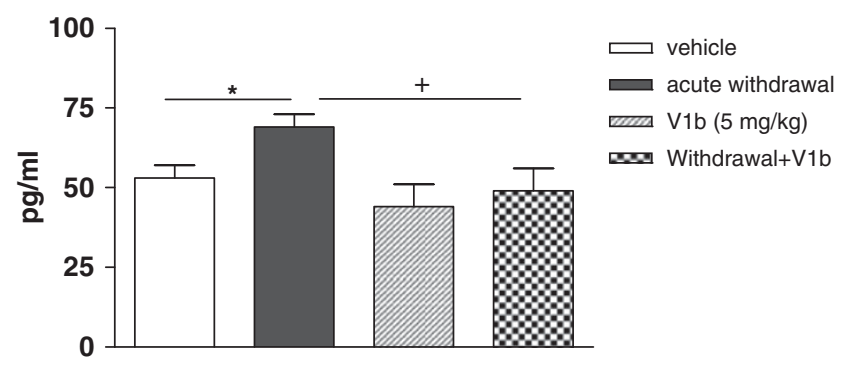

b plasma CORT of 1-day withdrawn rats

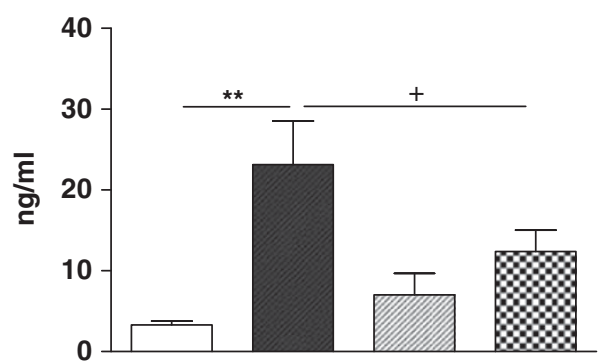

Figure 3 Effects of chronic (14-day) escalating-dose (45 up to $90 \mathrm{mg} / \mathrm{kg} /$ day) 'binge' cocaine (EDC) followed by acute (I-day) withdrawal with VIb receptor antagonist SSRI494I5 (5 mg/kg) on plasma ACTH levels (a) and corticosterone (CORT) levels (b). Data shown in graphs are treatment group mean + SEM. Significant differences are indicated: $* p<0.05$ or *** $p<0.0$ I vs saline control; $+p \leqslant 0.05$ vs I-day withdrawal $(n=6-8)$.
SSR149415 significantly blunted plasma ACTH increase after 1-day withdrawal $\left(\mathrm{df}_{(1,22)}=6.16, p<0.05\right)$.

As shown in Figure $3 \mathrm{~b}$, plasma CORT levels showed a similar pattern as seen in plasma ACTH. Two-way ANOVA showed a significant effect of 1-day withdrawal $\left(\mathrm{F}_{(1,25)}=10.6, p<0.005\right)$. Newman-Keuls post hoc tests showed (1) plasma CORT levels were significantly increased in 1-day withdrawal $(p<0.05)$ and $(2)$ pretreatment with SSR149415 blunted plasma CORT increase after 1-day withdrawal, without reaching statistical significance $(p=0.05)$.

Effects on AVP or CRF mRNA levels in the PVN, or on $V 1 b$ receptor $m R N A$ levels in the anterior pituitary.

AVP $m R N A$ in the PVN: After 1 day of acute 'binge' cocaine, there was no effect on AVP mRNA levels (data not shown). After 14 days of EDC, a Student's $t$-test just failed to show a significant difference between saline and 14-day EDC groups (Figure 4a). For 1-day withdrawal from chronic EDC, two-way ANOVA showed a significant effect of 1-day withdrawal $\left(\mathrm{F}_{(1,20)}=4.89, p<0.05\right)$ or naloxone $\left(\mathrm{F}_{(1,20)}=\right.$ $5.02, p<0.05)$ on AVP mRNA levels. Newman-Keuls post hoc tests were carried out and showed a significant difference between saline and each of the other three groups $(p<0.05)$. For 14 -day withdrawal, two-way ANOVA showed a significant effect of 14-day withdrawal $\left(\mathrm{F}_{(1,20)}=8.31, p<0.01\right)$. Newman-Keuls post hoc tests, however, just failed to show any significant effect for either treatment $(p=0.06)$.

As shown in Figure $4 \mathrm{~b}$, no difference from the controls was found on AVP mRNA levels in the PVN either after 14 days of chronic steady-dose 'binge' cocaine, or its 1- or 10-day withdrawal.

$V 1 b m R N A$ in the anterior pituitary: There was no effect on V1b mRNA levels after 1 day of acute 'binge' cocaine (data not shown). However, there was a significant increase after 14 days of $\operatorname{EDC}(t=22.3, \mathrm{df}=11, p<0.001$; Figure $4 \mathrm{c})$. For 1-day withdrawal, two-way ANOVA showed a significant effect of 1-day withdrawal $\left(\mathrm{F}_{(1,18)}=16.5, p<0.001\right)$ on V1b mRNA levels. Newman-Keuls post hoc tests showed a significant difference between saline and 1-day withdrawal groups $(p<0.05)$, or saline and naloxone + 1-day withdrawal groups $(p<0.05)$. For 14-day withdrawal, two-way ANOVA showed no significant effect on V1b mRNA levels.

As shown in Figure 4d, no difference from the controls was found on $\mathrm{V} 1 \mathrm{~b}$ receptor mRNA levels in the anterior pituitary either after 14 days of chronic steady-dose 'binge' cocaine, or its 1- or 10-day withdrawal.

CRF mRNA in the PVN: As shown in Supplementary Table S1, no difference in CRF mRNA levels in the PVN was detected between saline controls and after 1- or 14-day withdrawal from chronic escalating-dose 'binge' cocaine.

Effects on POMC $m R N A$ levels in the anterior pituitary or NIL/PL. As shown in Figure 5a, there was a significant increase in POMC mRNA levels after 14 days of EDC $(t=9.45, \mathrm{df}=11, p<0.05)$. For 1-day withdrawal, two-way ANOVA showed a significant effect of 1-day withdrawal $\left(\mathrm{F}_{(1,21)}=8.22, \quad p<0.01\right) \quad$ or naloxone $\times 1$-day withdrawal 
a

AVP in PVN of EDC rats

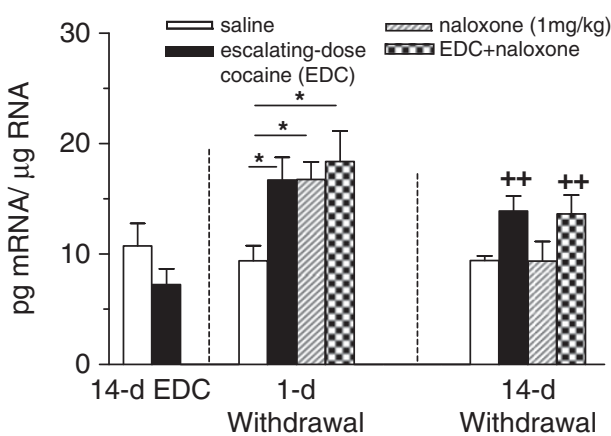

C $\quad \mathrm{V} 1 \mathrm{~b}$ in anterior pituitary of EDC rats

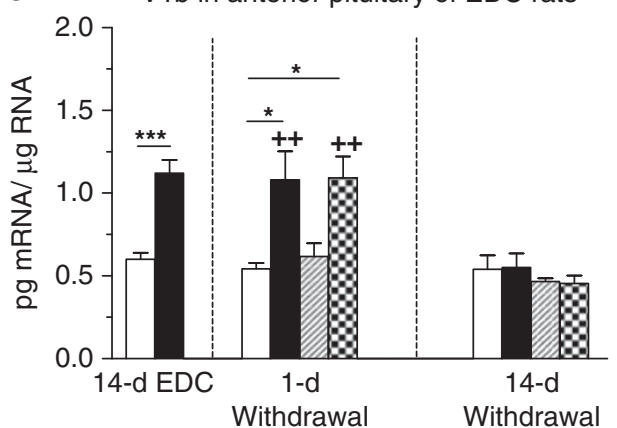

b

AVP in PVN of SDC rats
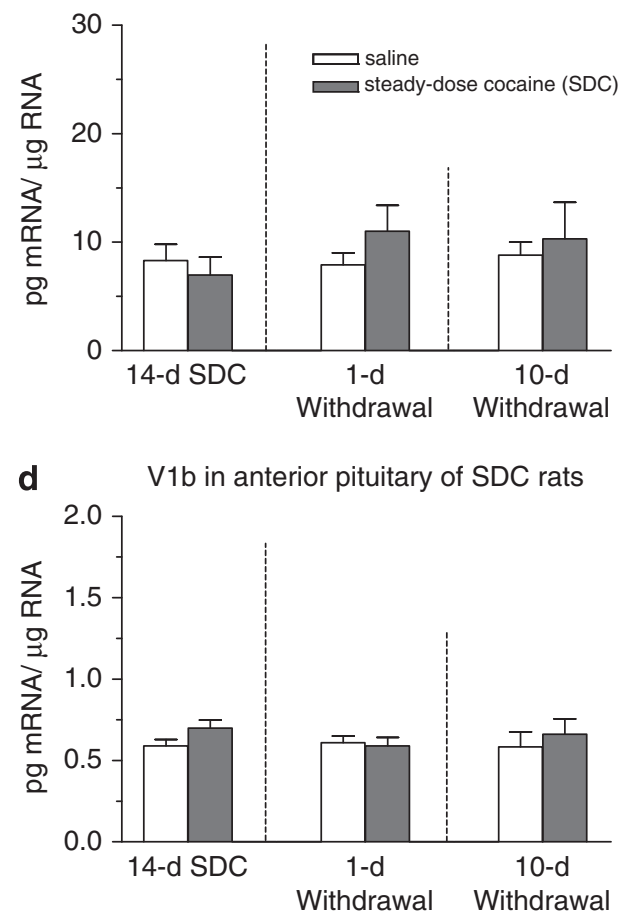

Figure 4 Effects of chronic (I4-day) escalating-dose (45 up to $90 \mathrm{mg} / \mathrm{kg} / \mathrm{day}$ ) 'binge' cocaine (EDC) or chronic (I4-day) steady-dose (45 mg/kg/day) 'binge' cocaine (SDC), acute (I-day) withdrawal and chronic (I0- or |4-day) withdrawal with opioid receptor antagonist naloxone (I mg/kg) on mRNA levels of AVP in the PVN $(a, b)$ and VIb in the anterior pituitary $(c, d)$. $* p<0.05$ or $* * * * 2<0.00$ I vs saline control; $++p<0.0$ I, two-way ANOVA with a significant main effect for I-day or 14-day withdrawal $(n=6-7)$.

a
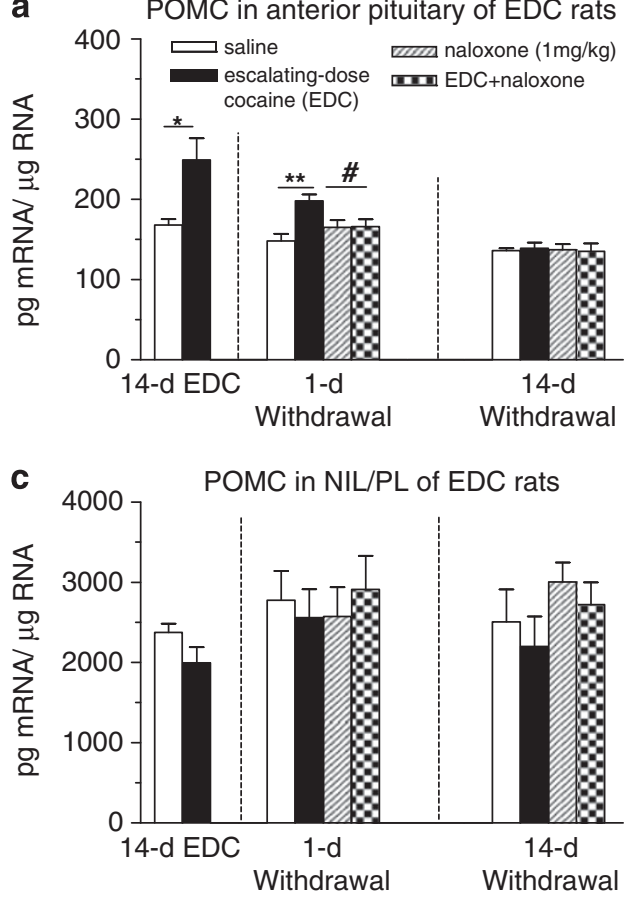

b $\quad$ POMC in anterior pituitary of SDC rats
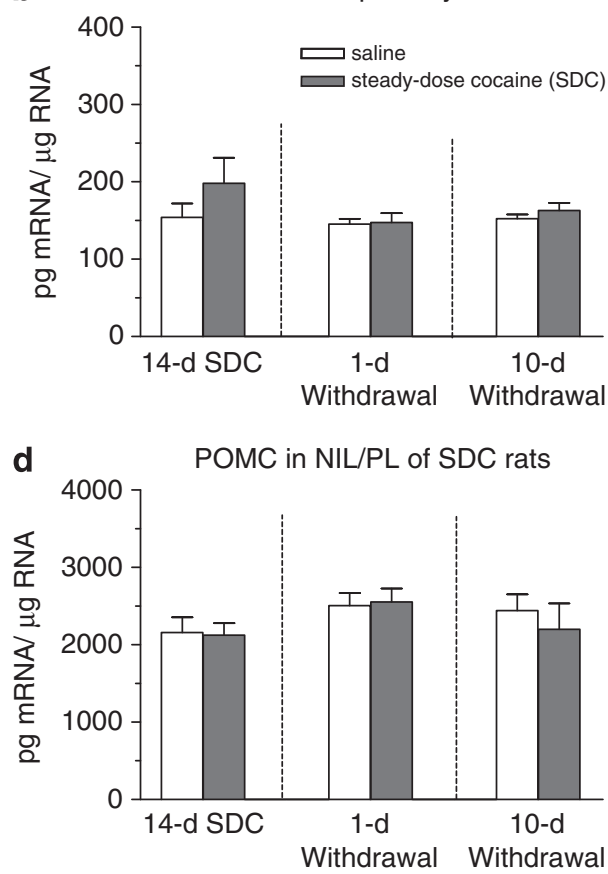

Figure 5 Effects of chronic ( 14 -day) escalating-dose (45 up to $90 \mathrm{mg} / \mathrm{kg} / \mathrm{day}$ ) 'binge' cocaine (EDC) or chronic (I4-day) steady-dose (45 mg/kg/day) 'binge' cocaine (SDC), acute (I-day) withdrawal and chronic (I0- or I4-day) withdrawal with opioid receptor antagonist naloxone (I mg/kg) on POMC mRNA levels in the anterior pituitary (a, b) and neuro-intermediate lobe/posterior lobe of the pituitary (c, $d)$. $* p<0.05$ or $* * p<0.0$ I vs saline control; $\# p<0.05$ vs EDC + I-day withdrawal $(n=6-7)$. 
interactions $\left(\mathrm{F}_{(1,21)}=7.39, p<0.05\right)$ on POMC mRNA levels. Newman-Keuls post hoc tests showed a significant difference between saline and 1-day withdrawal groups $(p<0.01)$, or between 1-day withdrawal and naloxone +1-day withdrawal groups $(p<0.05)$. For 14 -day withdrawal, there was no significant effect on POMC mRNA levels in the anterior pituitary after either treatment.

As shown in Figure 5b, no difference from the controls was found on POMC mRNA levels in the anterior pituitary after 14 days of chronic steady-dose 'binge' cocaine, or its 1- or 10-day withdrawal.

In the NIL/PL, there was no significant effect on POMC mRNA levels after 14 days of either EDC or SDC, or withdrawal with or without naloxone treatment (Figure $5 c$ and $d)$.

\section{Experiment 3: Acute Withdrawal from Chronic} Escalating-Dose 'Binge' Pattern Cocaine Administration in AVP-EGFP Promoter Transgenic Mice

Expression of EGFP from the AVP promoter in the PVN and MPOA. The co-expression of AVP-immunoreactive (ir) peptide with EGFP in the PVN and MPOA was verified by IHC analysis using two male AVP-EGFP $(+)$ mice (after acute cocaine withdrawal), in which the AVP promoter drives EGFP expression. As shown in Figure 6, IHC for AVP-ir demonstrated $\sim 90 \%$ colocalization of AVP-ir with the EGFP-expressing neurons in the PVN (Figure 6a) and MPOA (Figure 6b). Cells containing AVP-EGFP were distributed in the PVN. The largest amount of AVP-EGFPpositive cells was among magnocellular neurons (Figure 6a), but many parvocellular neurons were also observed. AVPEGFP-expressing cells were also distributed in the MPOA (Figure 6b), and the SON (data not shown), with no reliable fluorescence signals in the bed nucleus of the stria terminalis or medial amygdala.

Single-cell RT-PCR to verify co-expression of AVP $m R N A$ with EGFP in the PVN. Results from single-cell RT-PCR showed a highly significant difference between $\operatorname{EGFP}(+)$ and EGFP $(-)$ neurons when analyzing group differences in delta $C^{\mathrm{t}}$ values (Table 1). Equivalent significant changes were also found in AVP/18S ratios $(t=4.40, \mathrm{df}=14$, $p<0.001$ ) (data not shown). These findings verify selective co-expression of AVP mRNA with EGFP in the PVN. As expected, no-RT and water controls showed no amplification ( $n=2$ each, per group) and the expression of $18 \mathrm{~S}$ was high and did not differ between $\operatorname{EGFP}(+)$ and $\operatorname{EGFP}(-)$ cells.

One-day withdrawal from 14-day escalating-dose 'binge' cocaine. In the AVP-EGFP $(+)$ mice treated with saline, AVP-EGFP expression was observed in the PVN under fluorescence microscopy. AVP-EGFP-expressing cells were mainly localized in the magnocellular division of the PVN, with a few parvocellular neurons (Figure 7). After acute (1-day) withdrawal from chronic EDC, the AVP-EGFP(+) mice showed a significant increase in total number of AVPEGFP-expressing cells in the PVN $(t=14.0, \mathrm{df}=10, p<0.01$; Figure 7; Table 2). The increase was primarily in the parvocellular division of the PVN, with no change in the magnocellular division (Figure 7). In the AVP-EGFP(-) a

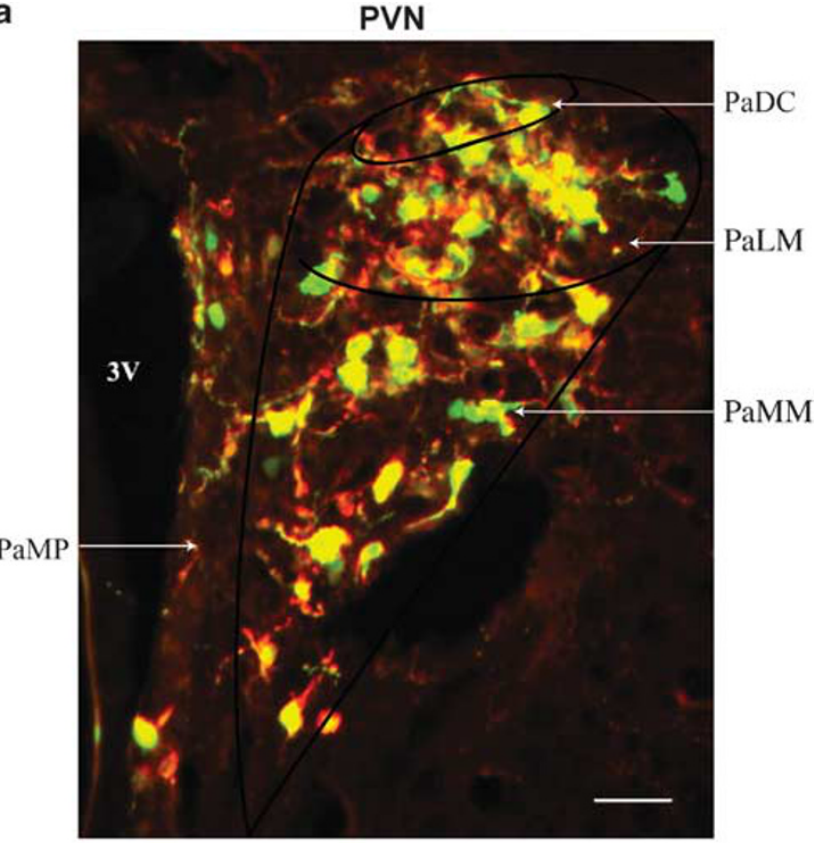

b

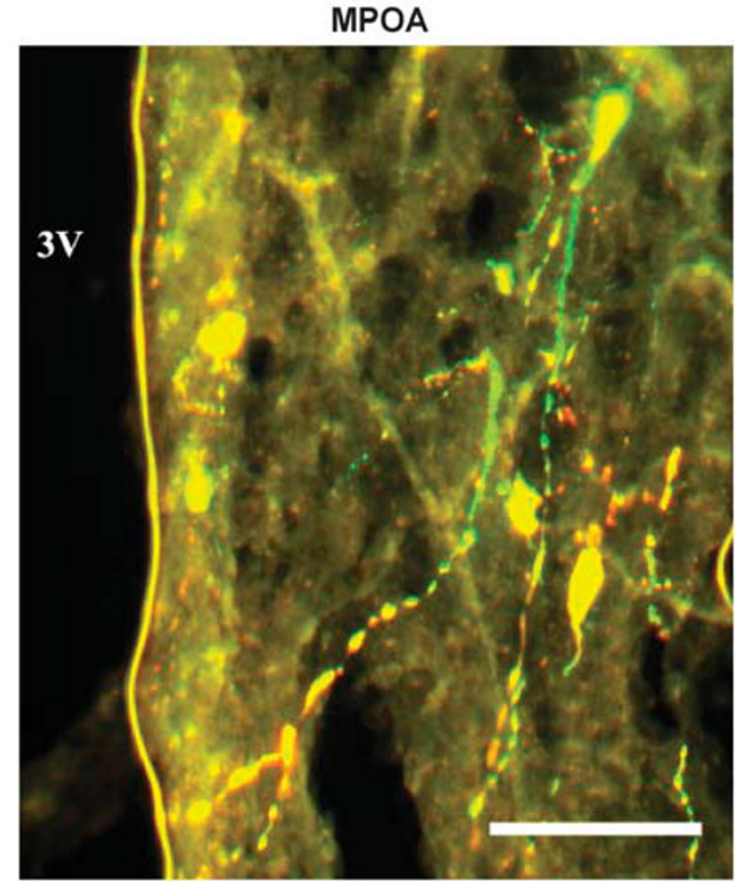

Figure 6 Colocalization of AVP-immunoreactive (ir) and EGFP in AVPEGFP-expressing neurons of paraventricular nucleus (PVN, Bregma $-0.82 \mathrm{~mm}$ ) (a) and medial preoptic area (MPOA, Bregma $-0.22 \mathrm{~mm}$ ) (b) of AVP-EGFP $(+)$ promoter transgenic mice: AVP-EGFP neurons expressing EGFP (green), AVP-ir neurons labeled with AVP antibody (red), and AVP-EGFP neurons co-expressing AVP-ir and EGFP (yellow) in the PVN and MPOA. The scale bar represents $50 \mu \mathrm{m}$. PaDC, paraventricular hypothalamic nucleus, dorsal cap; PaLM, paraventricular hypothalamic nucleus, lateral magnocellular part; PaMM, paraventricular hypothalamic nucleus, medial magnocellular part; PaMP, paraventricular hypothalamic nucleus, medial parvocellular part.

mice, AVP mRNA levels in the PVN of saline control and acute cocaine withdrawal were $6.5 \pm 1.1$ and $12.5 \pm 1.7 \mathrm{pg} / \mu \mathrm{g}$ total RNA, respectively, and acute cocaine withdrawal caused a significant increase $(t=8.41, \mathrm{df}=11, p<0.05)$. 
Table I Co-Expression of EGFP and AVP Was Verified by Assessing AVP and I8S (Housekeeping Gene) Expression in $\operatorname{EGFP}(+)$ and EGFP(-) Single Neurons Collected from the PVN Using the Taqman Detection System and Prism 7700 (Both Applied Biosystems)

\begin{tabular}{lll}
\hline Cell type & AVP primer & I8S primer \\
\hline AVP-EGFP(+) & $28.54 \pm 0.47$ & $19.45 \pm 0.43$ \\
AVP-EGFP(-) & $32.25 \pm 0.7 * * *$ & $19.21 \pm 0.26$ \\
\hline
\end{tabular}

Table represents mean cycle threshold $\left(C^{t}\right) \pm$ SEM in which AVP and I $8 \mathrm{~S}$ genes were amplified. Lower values represent higher mRNA levels. Student's twotailed $t$-tests were run on the individual $\Delta C^{t}$ values (AVP $C^{t}$ minus $18 S C^{t}$ ) and showed a significant difference between AVP-EGFP $(+)$ and AVP-EGFP $(-)$ groups. $* * * * 00001 ; n=8$ per group.
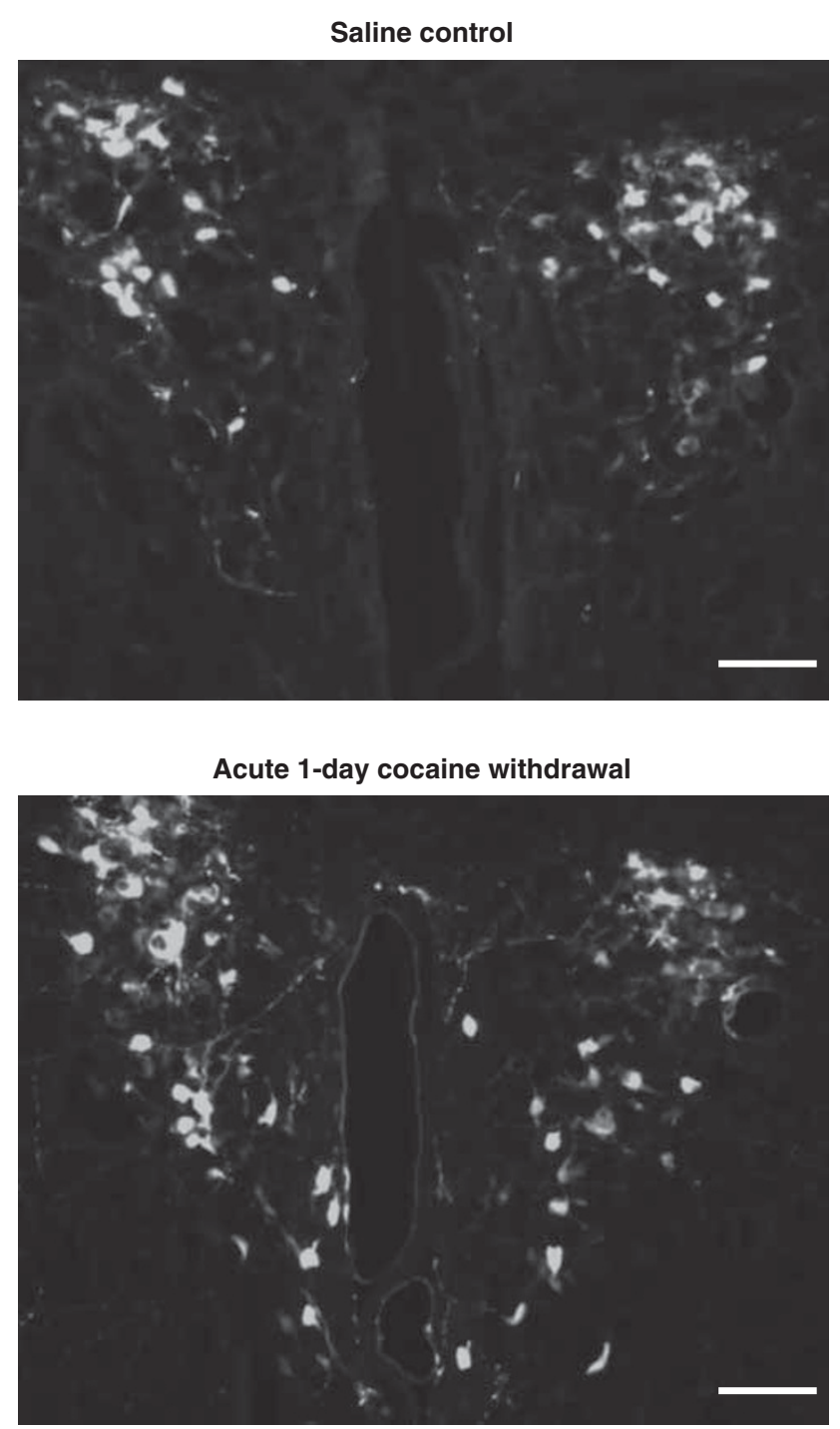

Figure 7 Effects of acute (I-day) withdrawal from chronic (|4-day) escalating-dose (45 up to $90 \mathrm{mg} / \mathrm{kg} /$ day) 'binge' cocaine on the number of AVP-EGFP-expressing neurons in the paraventricular nucleus (PVN) of AVP-EGFP $(+)$ promoter transgenic mice. Sections of the PVN from saline control (upper) and acute cocaine withdrawal (lower) treated AVPEGFP(+) mice. The scale bar represents $50 \mu \mathrm{m}$. AVP-EGFP expression in the PVN was quantified by measuring the number of EGFP-expressing cells (Table 2).
Table 2 Effects of Acute (I-day) Withdrawal from Chronic ( I4-day) Escalating-Dose (45 up to $90 \mathrm{mg} / \mathrm{kg} /$ day) 'Binge' Cocaine on the Number of AVP-EGFP-Expressing Neurons in the Paraventricular Nucleus (PVN) and Medial Preoptic Area (MPOA) of AVP-EGFP(+) Promoter Transgenic Mice

\begin{tabular}{lcc}
\hline Brain region & Saline control & I-day withdrawal \\
\hline $\mathrm{PVN}$ & $52 \pm 3$ & $67 \pm 7 * *$ \\
$\mathrm{MPOA}$ & $4 \pm 1$ & $9 \pm 2 *$ \\
\hline
\end{tabular}

AVP-EGFP expression in the PVN and MPOA was quantified by measuring the number of EGFP-expressing cells. Student's two-tailed $t$-tests showed a significant difference between I-day withdrawal and saline control groups. $* p<0.05, * * p<0.01 ; n=6-7$.

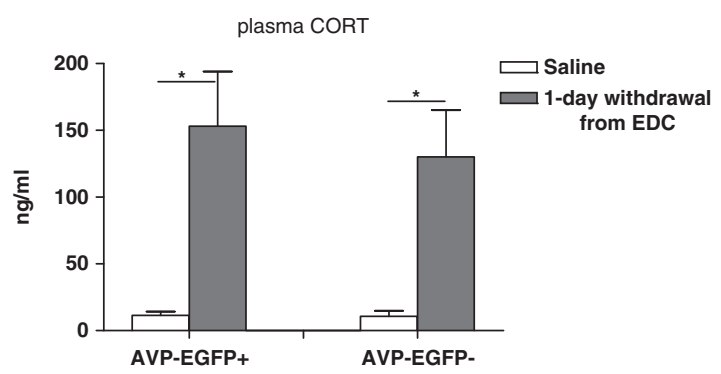

Figure 8 Effects of acute ( I-day) withdrawal from chronic (I4-day) escalating-dose (45 up to $90 \mathrm{mg} / \mathrm{kg} / \mathrm{day}$ ) 'binge' cocaine on plasma corticosterone (CORT) levels in both AVP-EGFP $(+)(n=6)$ and AVPEGFP $(-)(n=6-7)$ promoter transgenic mice. ${ }^{*} p<0.05$ vs saline control.

After acute cocaine withdrawal, the number of AVPEGFP-expressing cells was also increased in the MPOA $(t=12.1, \mathrm{df}=6, p<0.05$; Table 2$)$, but not in the SON (data not shown).

To examine the HPA functionality to stress, we compared the $\operatorname{AVP}-\operatorname{EGFP}(+)$ and $\operatorname{AVP}-\operatorname{EGFP}(-)$ mice after acute (1-day) cocaine withdrawal from chronic (14-day) EDC. Two-way ANOVA showed a significant effect of 1-day withdrawal on plasma CORT levels $\left(\mathrm{F}_{(1,22)}=18.4, p<0.001\right)$. Newman-Keuls post hoc tests were carried out and revealed a significant difference between saline and 1-day withdrawal in each genotype $(p<0.05$; Figure 8$)$. Our result clearly showed that there were similar increases in plasma CORT levels after 1-day acute withdrawal in AVP-EGFP $(+)$ and AVP-EGFP $(-)$ mice, indicating normal HPA stress responsivity in the AVP-EGFP $(+)$ mice.

\section{DISCUSSION}

\section{HPA Hormones}

In the present study, we found that 14 days of chronic EDC administration significantly elevated plasma ACTH and CORT levels, when rat blood was sampled at the nadir time point of the day. In contrast to the lack of ACTH elevation after 14-day SDC administration, there was a 7-fold ACTH increase on day 14 with the escalating-dose regimen, indicating dramatic HPA axis stimulation by escalated high-dose cocaine. In the EDC-treated rats, plasma ACTH 
and CORT levels remained significantly increased after acute (1-day) withdrawal, an effect that persisted into protracted (14-day) withdrawal. In the animal literature, the effects of acute cocaine withdrawal on the HPA axis are consistent even when using different administration paradigms. For example, chronic cocaine exposure (15-45 mg/ $\mathrm{kg} /$ day) for 2 weeks has been reported to increase basal plasma CORT levels after 1 day of withdrawal (Borowsky and Kuhn, 1991; Levy et al, 1992; Sarnyai et al, 1998; Peltier et al, 2001; Zorrilla et al, 2001; Zhou et al, 2003; Picetti et al, 2010). Therefore, our present finding is consistent with and extends reports from other laboratories, demonstrating persistent HPA axis activation, with much longer duration after the cessation of chronic EDC. In addition, our result here is in agreement with several clinical reports showing higher basal plasma ACTH and cortisol levels in cocaine addicts after several weeks' cessation of cocaine selfadministration (Elman et al, 1999; Buydens-Branchey et al, 2002; Contoreggi et al, 2003; Wilkins et al, 2005; Fox et al, 2009).

\section{AVP Gene Expression in the pPVN}

A single injection of cocaine increases CRF (but not AVP) mRNA levels in the rat PVN (Rivier and Lee, 1994; Zhou et al, 1996), indicating an involvement of hypothalamic CRF in modulating the stimulatory effects of acute cocaine on the HPA axis. In contrast to acute cocaine, our previous study showed that acute withdrawal did not cause any increase in CRF mRNA levels in the hypothalamus (Zhou et al, 2003). The present study was designed to examine another important hypothalamic secretagogue, AVP, after cocaine withdrawal. In fact, we identified that withdrawal from different doses of cocaine corresponded to significant differences in PVN AVP mRNA levels. After acute (1-day) withdrawal, there was a significant increase in AVP mRNA levels (by 78\%) in the PVN of the EDC-treated rats, which was not seen in the SDC-treated animals. This increase seems long lasting: AVP mRNA levels were still found to be $46 \%$ higher after 14 days of protracted withdrawal. It has been demonstrated that AVP in the PVN is involved in mediation of long-lasting changes in sensitivity and responsivity of the HPA axis to subsequent stimuli (Kovacs and Sawchenko, 1996; Aguilera and Rabadan-Diehl, 2000). The alterations in AVP mRNA levels reported here could be the result of enhanced AVP promoter activity, leading to an increased AVP gene transcriptional rate (see data in AVPEGFP promoter transgenic mice). This increase in AVP gene expression could further lead to an increase in AVP biosynthesis and/or release from the median eminence as well as, in turn, in the production of ACTH from the anterior pituitary by cocaine withdrawal. Indeed, we observed that, although both the EDC and SDC rats showed increased HPA activity after 1-day acute withdrawal, the EDC rats displayed significantly longer HPA stimulation in response to cocaine withdrawal than the SDC animals. This strong temporal correlation between PVN AVP gene expression and HPA activity suggests a potential role for AVP in modulating the HPA axis during cocaine withdrawal. It is possible that the large quantities of this psychostimulant led to a dysregulation of stress pathways that enhanced hypothalamic stress responsive gene expressions, including AVP. Thereby, the enhanced AVP activity contributes to the persistent increases in the HPA activity observed during protracted withdrawal. In accordance with this notion, pretreatment with the selective V1b antagonist SSR149415 attenuated HPA activity during acute cocaine withdrawal. This result also suggests that the HPA activation was partially mediated through $\mathrm{V} 1 \mathrm{~b}$ receptors, which are expressed in the corticotropic ACTH-positive cells (Hernando et al, 2001), and modulate HPA axis activity in response to a variety of stressors (Roper et al, 2011) (see more discussion below).

To further investigate the changes of AVP expression in the magnocellular and parvocellular divisions of the PVN, we utilized the AVP-EGFP promoter transgenic mice to visualize the AVP neurons in these two sub-populations in response to acute cocaine withdrawal. After qualitative assessment (cell counting) of AVP-EGFP-expressing neurons in the PVN, we found an increase in the number of AVP-EGFP neurons in the parvocellular division (but not in the magnocellular division) after acute (1-day) withdrawal from chronic EDC in AVP-EGFP $(+)$ mice. This elevated promoter activity in the AVP-EGFP neurons associated with increased AVP mRNA levels suggests an enhanced AVP gene transcription. This parvocellular AVP-EGFP increase was also paralleled in increased plasma CORT levels by acute withdrawal. Our results are in accordance with many previous reports in rodents demonstrating an activation of AVP gene expression in the pPVN in modulation of the HPA axis after chronic stress (Herman, 1995; Kovacs and Sawchenko, 1996; Viau et al, 1999; Aguilera and RabadanDiehl, 2000). Together, our results suggest an involvement of the pPVN AVP neurons in the modulation of the HPA axis response to acute cocaine withdrawal stress. Here, we were only able to measure the number of AVP-EGFPexpressing neurons. We were not, however, able to assess the strength of EGFP fluorescence in order to quantify the visual density of AVP-EGFP fluorescence in individual neurons; thus, we could not measure the changes of AVPEGFP density in individual cells.

\section{V1b Receptor in the Anterior Pituitary}

It has been suggested that chronic exposure to cocaine, like many stressors, may modulate HPA responsivity at the corticotrope level (eg, Aguilera and Rabadan-Diehl, 2000). $\mathrm{V} 1 \mathrm{~b}$ receptor expression in the anterior pituitary is preferentially associated with ACTH-positive cells (Hernando et al, 2001), and is stimulated (but not inhibited) by glucocorticoids (Aguilera and Rabadan-Diehl, 2000). Thus, alterations of $\mathrm{V} 1 \mathrm{~b}$ receptor and $\mathrm{POMC}$ in the anterior pituitary following chronic cocaine and its withdrawal are particularly interesting. In fact, a significant increase of both the V1b receptor and POMC mRNA levels was found after chronic EDC administration, but not after a steadydose regimen. In parallel, plasma ACTH and CORT levels rose dramatically in response to cocaine, suggesting that EDC may modulate corticotrope responsivity to pPVN AVP input through the induction of $\mathrm{V} 1 \mathrm{~b}$ and POMC gene expression. Our study further showed that the increase of both $\mathrm{V} 1 \mathrm{~b}$ and POMC gene expression persisted 1 day into acute withdrawal, and the activation of the HPA axis during withdrawal was prolonged in the EDC rats rather than in the 
SDC animals. Regardless of the exact mechanisms responsible for the interactions between cocaine and the V1b receptor, our results suggest that the HPA activation by chronic cocaine and its withdrawal may be related to the increased $\mathrm{V} 1 \mathrm{~b}$ receptor expression in the anterior pituitary.

\section{Interaction between pPVN AVP and Opioid Receptors}

After a single injection of an opioid receptor antagonist naloxone $(1 \mathrm{mg} / \mathrm{kg})$, there was an increase in rat PVN AVP mRNA levels after 1 day (but not after 2 days). Our results clearly show that the blockade of opioid receptors increased AVP gene expression in the PVN, indicating an inhibition of AVP activity by endogenous opioids, as suggested by a recent study on naloxone-induced AVP gene expression in the parvocellular (but not in magnocellular) neurons during morphine withdrawal (Nunez et al, 2007). There was an elevation of plasma ACTH levels after $3 \mathrm{~h}$ of naloxone $(1 \mathrm{mg} / \mathrm{kg}$ ) as previously reported (Zhou et al, 2005). After 1-2 days of naloxone injection, however, there was no elevation of plasma ACTH levels observed in the present study, suggesting that ACTH elevation could return to basal levels, due to the short-acting property of naloxone. Of particular interest, AVP gene expression that increased by protracted cocaine withdrawal was insensitive to opioid receptor blockade, since we observed no effect of naloxone on AVP mRNA levels during cocaine withdrawal, which suggests less inhibition of AVP neurons by endogenous opioids in cocaine-withdrawn rats. Studies in human cocaine addicts found a decreased opioid activity ( $\mu$ opioid receptor-preferring component) in the control of the HPA axis (Schluger et al, 2001; Koob and Kreek, 2007), supporting this relative endogenous opioid-deficiency hypothesis. Although the naloxone dose in the present study was relatively low and preferential for the $\mu$ opioid receptor, we cannot at this point exclude the involvement of other opioid receptors, such as $\kappa$ opioid receptors.

\section{AVP in the MPOA}

AVP neurons are localized in the MPOA (Rhodes et al, 1981), a region that is directly responsive to cocaine: sitespecific infusion of cocaine into the MPOA has been shown to impair maternal behavior in rats (Vernotica et al, 1999). Since intra-MPOA injection of AVP induces grooming behavior in mice (Lumley et al, 2001), our present finding suggests that the AVP-EGFP-expressing neurons in the MPOA are involved in cocaine withdrawal-related behaviors.

\section{Summary}

Our results indicate that chronic EDC and its withdrawal can dynamically modulate HPA axis activity in both rats and mice. Since the biochemical measures using rats demonstrated strong temporal associations between PVN AVP gene expression, pituitary V1b receptor gene expression, and HPA activity during its protracted withdrawal from chronic EDC, our study clearly suggests a potential novel role for AVP and its V1b receptor in modulating the stress responsive HPA axis after chronic cocaine administration. Our pharmacologic data with the selective V1b
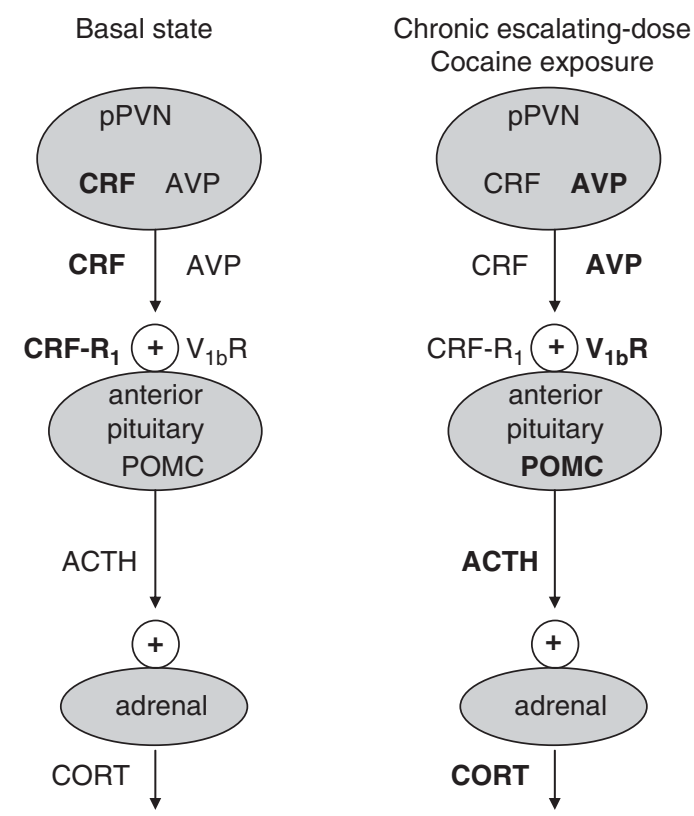

Figure 9 Schematic representation of the alterations of HPA axis after chronic escalating-dose cocaine exposure in rodents. After acute cocaine, previous work has demonstrated that CRF (but not AVP) contributes to acute stimulatory effects of cocaine on HPA activity (left side). After chronic cocaine, however, there are increases in AVP promoter activity and gene expression in the parvocellular division of the paraventricular nucleus (pPVN) following acute withdrawal (right side). This is also paralleled with the increases in VIb gene expression in the anterior pituitary, and the elevations of plasma ACTH and corticosterone levels. The increase in pPVN AVP gene expression persists into protracted (14-day) cocaine withdrawal.

receptor antagonist provide further evidence that there is an involvement of the $\mathrm{AVP} / \mathrm{V} 1 \mathrm{~b}$ receptor system in acute cocaine withdrawal. Using AVP-EGFP promoter transgenic mice, we identified that acute cocaine withdrawal specifically activated the parvocellular AVP-EGFP neurons in the PVN (Figure 9).

A growing body of evidence suggests that increased vasopressinergic neuronal activity in the hypothalamus, amygdala and other brain regions represents an important step in the neurobiology of stress-related and drug withdrawal-induced behaviors in rodent models, including 'anxiety' and 'depression'-like behavior (Wigger et al, 2004; Zhou et al, 2005; Murgatroyd et al, 2009; RodríguezBorrero et al, 2010). In humans, cessation of prolonged cocaine consumption is usually accompanied by an aversive withdrawal syndrome characterized by mild depressive symptoms combined with anxiety, irritability, and anhedonia that may last up to several weeks (American Psychiatric Association, Diagnostic and Statistical Manual of Mental Disorders, vol. 4, 1994). Moreover, this aversive affective state observed in both humans and animals provides a powerful source of negative reinforcement (Koob, 2008). Since rats and mice display increased AVP expression upon cocaine withdrawal, one interesting hypothesis that stems from our present study is that AVP may have a role in cocaine-seeking behaviors. An interesting question is whether AVP modulates cocaine self-administration behavior through a $\mathrm{V} 1 \mathrm{~b}$ receptor-mediated mechanism, as found in animal models of heroin seeking and alcohol 
dependence (Zhou et al, 2008b; Edwards et al, 2011). An ongoing study has been undertaken in our laboratory to investigate the effects of pharmacological blockade of V1b receptor on stress-induced reinstatement of cocaine selfadministration. Therefore, it may be worthwhile to explore the value of AVP receptor antagonists in the management of cocaine abuse. Our studies indicate that AVP and its receptor system may be an attractive therapeutic target for treating anxiety and depressive symptoms associated with cocaine addiction.

\section{ACKNOWLEDGEMENTS}

We would like to thank Professor N Heintz and Dr L Kus of the GENSAT Program at The Rockefeller University for providing the AVP-EGFP transgenic mice; Dr G Aguilera for the vasopressin and V1b receptor cDNAs; Dr JL Roberts for the POMC cDNA; Drs T Nilsen and P Maroney for the 18S cDNA; and Dr G Griebel for SSR149415. This work was supported by NIDA Research Center Grant DA-P50-05130 (MJK) and HD-05751 (DWP).

\section{DISCLOSURE}

The authors report no conflicts of interest. The authors alone are responsible for the content and writing of the paper.

\section{REFERENCES}

Aguilera G (1994). Regulation of pituitary ACTH secretion during chronic stress. Front Neuroendocrinol 15: 321-350.

Aguilera G, Rabadan-Diehl C (2000). Vasopressinergic regulation of the hypothalamic-pituitary-adrenal axis: implications for stress adaptation. Regul Pept 96: 23-29.

Antoni FA (1993). Vasopressinergic control of pituitary adrenocorticotropin secretion comes of age. Front Neuroendocrinol 14: 76-122.

Aouizerate B, Ho A, Schluger J, Perret G, Borg L, Le Moal M et al (2006). Glucocorticoid negative feedback in methadone-maintained former heroin addicts with cocaine dependence: doseresponse to dexamethasone suppression. Addict Biol 11: 84-96.

Back SE, Hartwell K, Desantis SM, Saladin M, McRae-Clark AL, Price KL et al (2010). Reactivity to laboratory stress provocation predicts relapse to cocaine. Drug Alcohol Depend 106: 21-27.

Borowsky B, Kuhn CM (1991). Chronic cocaine administration sensitizes behavioral but not neuroendocrine responses. Brain Res 543: 301-306.

Brady KT, McRae AL, Moran-Santa Maria MM, DeSantis SM, Simpson AN, Waldrop AE et al (2009). Response to corticotropin-releasing hormone infusion in cocaine dependent individuals. Arch Gen Psychiatry 66: 422-430.

Buydens-Branchey L, Branchey M, Hudson J, Majewska MD (2002). Perturbations of plasma cortisol and DHEA-S following discontinuation of cocaine use in cocaine addicts. Psychoneuroendocrinology 27: 83-97.

Contoreggi C, Herning RI, Koeppl B, Simpson PM, Negro Jr PJ, Fortner-Burton C et al (2003). Treatment-seeking inpatient cocaine abusers show hypothalamic dysregulation of both basal prolactin and cortisol secretion. Neuroendocrinology 78: 154-162.

Edwards S, Guerrero M, Ghoneim OM, Roberts E, Koob GF (2011). Evidence that vasopressin $\mathrm{V} 1 \mathrm{~b}$ receptors mediate the transition to excessive drinking in ethanol-dependent rats. Addict Biol. (in press).

Elman I, Breiter HC, Gollub RL, Krause S, Kantor HL, Baumgartner WA et al (1999). Depressive symptomatology and cocaineinduced pituitary-adrenal axis activation in individuals with cocaine dependence. Drug Alcohol Depend 56: 39-45.

Fox HC, Jackson ED, Sinha R (2009). Elevated cortisol and learning and memory deficits in cocaine dependent individuals: relationship to relapse outcomes. Psychoneuroendocrinology 34: 1198-1207.

Gillies GE, Linton EA, Lowry PJ (1982). Corticotropin releasing activity of the new CRF is potentiated several times by vasopressin. Nature 299: 355-357.

Gong S, Zheng C, Doughty ML, Losos K, Didkovsky N, Schambra $\mathrm{UB}$ et al (2003). A gene expression atlas of the central nervous system based on bacterial artificial chromosomes. Nature 425: 917-925.

Herman JP (1995). In situ hybridization analysis of vasopressin gene transcription in the paraventricular and supraoptic nuclei of the rat: regulation by stress and glucocorticoids. J Comp Neurol 363: 15-27.

Hernando F, Schoots O, Lolait SJ, Burbach JPH (2001). Immunohistochemical localization of the vasopressin $\mathrm{V} 1 \mathrm{~b}$ receptor in the rat brain and pituitary gland: anatomical support for its involvement in the central effects of vasopressin. Endocrinology 142: $1659-1668$.

Jacobsen LK, Giedd JN, Kreek MJ, Gottschalk C, Kosten TR (2001). Quantitative medial temporal lobe brain morphology and hypothalamic-pituitary-adrenal axis function in cocaine dependence: a preliminary report. Drug Alcohol Depend 62: 49-56.

Knepel W, Przewlocki R, Herz A (1985). Foot shock stress-induced release of vasopressin in adenohypophysectomized and hypophysectomized rats. Endocrinology 117: 292-299.

Koob GF (2008). A role for brain stress systems in addiction. Neuron 59: 11-34.

Koob GF, Kreek MJ (2007). Stress, dysregulation of drug reward pathways, and the transition to drug dependence. Am J Psychiatry 164: 1149-1159.

Kosten TA, Ambrosio E (2002). HPA axis function and drug addictive behaviors: insights from studies with Lewis and Fischer 344 inbred rats. Psychoneuroendocrinology 27: 35-69.

Kovacs KJ, Sawchenko PE (1996). Sequence of stress-induced alterations in indices of synaptic and transcriptional activation in parvocellular neurosecretory neurons. J Neurosci 16: 262-273.

Kreek MJ, Zhou Y, Butelman ER, Levran O (2009). Opiate and cocaine addiction: from bench to clinic and back to bench. Curr Opin Pharmacol 9: 74-80.

Levy AQ, Li Q, Sanz MCA, Rittenhouse PA, Kerr JE, Van De Kar LD (1992). Neuroendocrine responses to cocaine do not exhibit sensitization following repeated cocaine exposure. Life Sci 51: 887-897.

Lumley LA, Robison CL, Chen WK, Mark B, Meyerhoff JL (2001). Vasopressin into the preoptic area increases grooming behavior in mice. Physiol Behav 73: 451-455.

McEwen BS (2007). Physiology and neurobiology of stress and adaptation: central role of the brain. Physiol Rev 87: 873-904.

Mendelson JH, Sholar M, Mello NK, Teoh SK, Sholar JW (1998). Cocaine tolerance: behavioral, cardiovascular, and neuroendocrine function in men. Neuropsychopharmacology 18: 263-271.

Moldow RL, Fischman AJ (1987). Cocaine induced secretion of ACTH, beta-endorphin, and corticosterone. Peptides 8: 819-822.

Murgatroyd C, Patchev AV, Wu Y, Micale V, Bockmühl Y, Fischer $\mathrm{D}$ et al (2009). Dynamic DNA methylation programs persistent adverse effects of early-life stress. Nat Neurosci 12: 1559-1566.

Nomura M, McKenna E, Korach KS, Pfaff DW, Ogawa S (2002). Estrogen receptor-beta regulates transcript levels for oxytocin and arginine vasopressin in the hypothalamic paraventricular nucleus of male mice. Mol Brain Res 109: 84-94. 
Nunez C, Földes A, Laorden ML, Milanes MV, Kovács KJ (2007). Activation of stress-related hypothalamic neuropeptide gene expression during morphine withdrawal. J Neurochem 101: 1060-1071.

Peltier RL, Guerin GF, Dorairaj N, Goeders NE (2001). Effects of saline substitution on responding and plasma corticosterone in rats trained to self-administer different doses of cocaine. J Pharmacol Exp Ther 299: 114-120.

Picetti R, Ho A, Butelman ER, Kreek MJ (2010). Dose preference and dose escalation in extended-access cocaine self-administration in Fischer and Lewis rats. Psychopharmacology (Berl) 211: 313-323.

Rhodes CH, Morrell JI, Pfaff DW (1981). Immunohistochemical analysis of magnocellular elements in rat hypothalamus: distribution and numbers of cells containing neurophysin, oxytocin, and vasopressin. J Comp Neurol 198: 45-64.

Rivier C, Lee S (1994). Stimulatory effect of cocaine on ACTH section: role of the hypothalamus. Mol Cell Neurosci 5: 189-195.

Rivier C, Vale W (1983). Interaction of corticotropin-releasing factor and arginine vasopressin on adrenocorticotropin secretion in vivo. Endocrinology 113: 939-942.

Rodríguez-Borrero E, Rivera-Escalera F, Candelas F, Montalvo J, Muñoz-Miranda WJ, Walker JR et al (2010). Arginine vasopressin gene expression changes within the nucleus accumbens during environment elicited cocaine-conditioned response in rats. Neuropharmacology 58: 88-101.

Roper JA, O'Carroll A, Young III WS, Lolait SJ (2011). The vasopressin AVPr1b receptor: molecular and pharmacological studies. Stress 14: 98-115.

Sarnyai Z, Dhabhar FS, McEwen BS, Kreek MJ (1998). Neuroendocrine-related effects of long-term, 'binge' cocaine administration: diminished individual differences in stress-induced corticosterone response. Neuroendocrinology 68: 334-344.

Schluger JH, Borg L, Ho A, Kreek MJ (2001). Altered HPA axis responsivity to metyrapone testing in methadone maintained former heroin addicts with ongoing cocaine addiction. Neuropsychopharmacology 24: 568-575.

Serradeil-Le Gal C, Wagnon J, Simiand J, Griebel G, Lacour C, Guillon $\mathrm{G}$ et al (2002). Characterization of (2S,4R)-1-[5-chloro1-[(2,4-dimethoxyphenyl)sulfonyl]-3-(2-methoxy-phenyl)-2-oxo2,3-dihydro-1H-indol-3-yl]-4-hydroxy-N,N-dimethyl-2-pyrrolidine carboxamide (SSR149415), a selective and orally active vasopressin V1b receptor antagonist. J Pharmacol Exp Ther 300: 1122-1130.

Sinha R, Garcia M, Paliwal P, Kreek MJ, Rounsaville BJ (2006). Stress-induced cocaine craving and hypothalamic-pituitaryadrenal responses are predictive of cocaine relapse outcomes. Arch Gen Psychiatry 63: 324-331.

Vernotica EM, Rosenblatt JS, Morrell JI (1999). Microinfusion of cocaine into the medial preoptic area or nucleus accumbens transiently impairs maternal behavior in the rat. Behav Neurosci 113: $377-390$

Vescovi PP, Coiro V, Volpi R, Passeri M (1992). Diurnal variations in plasma ACTH, cortisol and beta-endorphin levels in cocaine addicts. Horm Res 37: 221-224.

Viau V, Chu A, Soriano L, Dallman MF (1999). Independent and overlapping effects of corticosterone and testosterone on corticotropin-releasing hormone and arginine vasopressin mRNA expression in the paraventricular nucleus of the hypothalamus and stress-induced adrenocorticotropic hormone release. J Neurosci 19: 6684-6693.

Westberg L, Sawa E, Wang AY, Gunaydin LA, Ribeiro AC, Pfaff DW (2009). Colocalization of connexin 36 and CRH in the mouse brain. BMC Neurosci 10: 41.

Wigger A, Sánchez MM, Mathys KC, Ebner K, Frank E, Liu D et al (2004). Alterations in central neuropeptide expression, release, and receptor binding in rats bred for high anxiety: critical role of vasopressin. Neuropsychopharmacology 29: 1-14.

Wilkins JN, Majewska MD, Van Gorp W, Li SH, Hinken C, Plotkin D et al (2005). DHEAS and POMS measures identify cocaine dependence treatment outcome. Psychoneuroendocrinology 30: 18-28.

Zhou Y, Bendor J, Yuferov V, Schlussman SD, Ho A, Kreek MJ (2005). Amygdalar vasopressin mRNA increases in acute cocaine withdrawal: evidence for opioid receptor modulation. Neuroscience 134: 1391-1397.

Zhou Y, Cui CL, Schlussman SD, Choi J, Ho A, Han JS et al (2008a). Effect of cocaine place conditioning, chronic escalatingdose binge pattern cocaine and its acute withdrawal on orexin/ hypocretin and preprodynorphin gene expressions in the lateral hypothalamus. Neuroscience 153: 1225-1234.

Zhou Y, Leri F, Cummins E, Hoeschele M, Kreek MJ (2008b). Involvement of arginine vasopressin and V1b receptor in heroin withdrawal and heroin seeking precipitated by stress and by heroin. Neuropsychopharmacology 33: 226-236.

Zhou Y, Spangler R, Ho A, Kreek MJ (2003). Increased CRH mRNA levels in the rat amygdala during acute withdrawal from chronic "binge" cocaine. Mol Brain Res 114: 73-79.

Zhou Y, Spangler R, LaForge KS, Maggos CE, Ho A, Kreek MJ (1996). Corticotropin-releasing factor and type 1 corticotropin-releasing factor receptor messenger RNAs in rat brain and pituitary during 'binge'-pattern cocaine administration and chronic withdrawal. J Pharmacol Exp Ther 279: 351-358.

Zorrilla EP, Valdez GR, Weiss F 2001. Changes in levels of regional CRF-like-immunoreactivity and plasma corticosterone during protracted drug withdrawal in dependent rats. Psychopharmacology 158: 374-381.

Supplementary Information accompanies the paper on the Neuropsychopharmacology website (http://www.nature.com/npp) 